\title{
Working
}

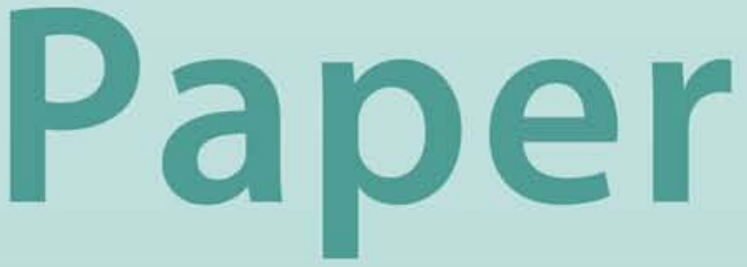




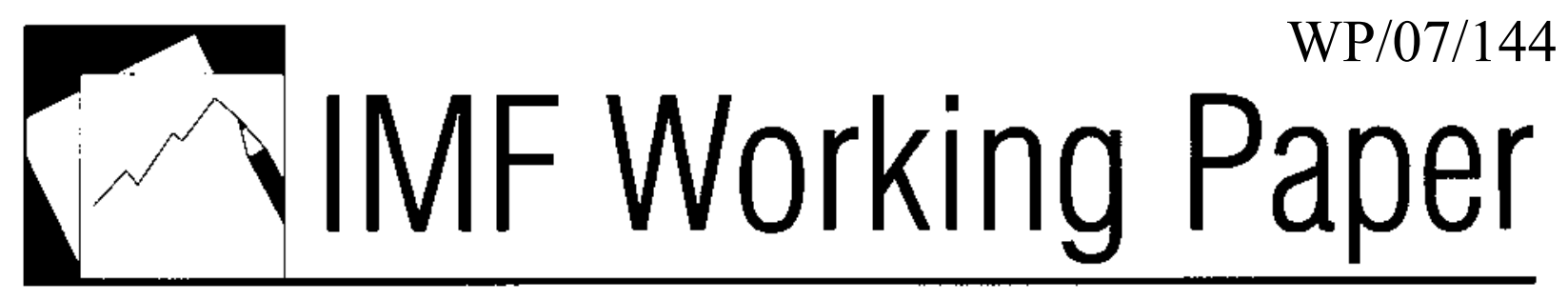

\section{Europe and Global Imbalances}

Philip R. Lane and Gian Maria Milesi-Ferretti 


\title{
IMF Working Paper
}

\author{
Research Department
}

\section{Europe and Global Imbalances}

\section{Prepared by Philip R. Lane and Gian Maria Milesi-Ferretti ${ }^{1}$}

June 2007

\begin{abstract}
This Working Paper should not be reported as representing the views of the IMF. The views expressed in this Working Paper are those of the author(s) and do not necessarily represent those of the IMF or IMF policy. Working Papers describe research in progress by the author(s) and are published to elicit comments and to further debate.

Although Europe in the aggregate is a not a major contributor to global current account imbalances, its trade and financial linkages with the rest of the world mean that it will still be affected by a shift in the current configuration of external deficits and surpluses. We assess the macroeconomic impact on Europe of global current account adjustment under alternative scenarios, emphasizing both trade and financial channels. Finally, we consider heterogeneous exposure across individual European economies to external adjustment shocks.
\end{abstract}

JEL Classification Numbers:F31, F32

Keywords: Financial integration, capital flows, external assets and liabilities

Author’s E-Mail Address:plane@tcd.ie; gmilesiferretti@imf.org

\footnotetext{
${ }^{1}$ Prepared for the Economic Policy Panel. We have benefited from the comments of the referees and the editors and participants in seminars at the ECB and European University Institute, plus conversations with Steve Kamin and Frank Warnock. We thank Vahagn Galstyan and Agustin Benetrix for excellent research assistance, and Sonali Jain-Chandra and Ivanna Vladkova-Hollar for their help in undertaking the simulations on valuation effects. Lane also gratefully acknowledges the financial support of the Irish Research Council on Humanities and Social Sciences (IRCHSS) and the HEA-PRTLI grant to the IIIS. The views expressed here are the authors' only and do not represent those of the IMF.
} 
I. Introduction

II. Europe’s external position in a global context

III. International Adjustment

A. Unwinding of Global Imbalances-A Model-Based Perspective ......................... $\frac{13}{13}$

B. A Brief Description of the Model .................................................................. 13

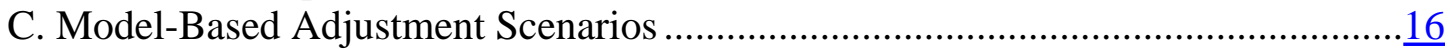

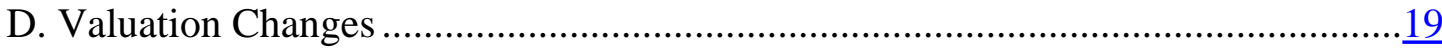

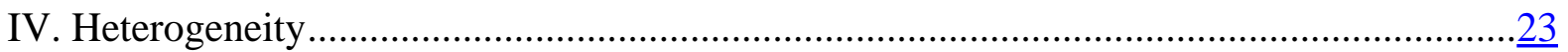

A. The Trade Channel ...............................................................................

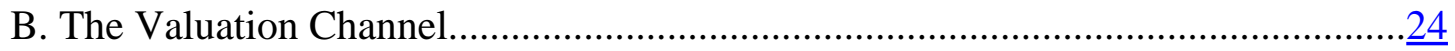

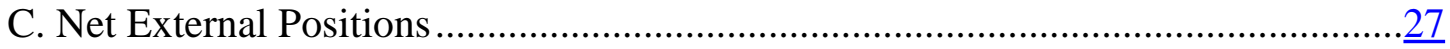

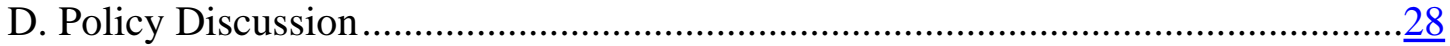

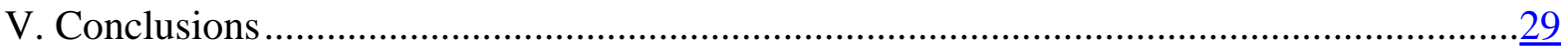

Appendices

1. Decomposition of Changes in Net Foreign Assets …...........................................31

2. Estimating the Currency Composition of Net Foreign Assets...................................33

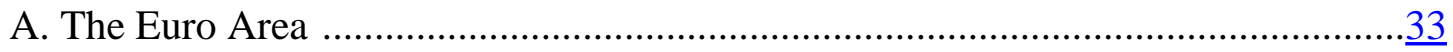

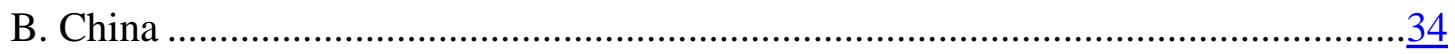

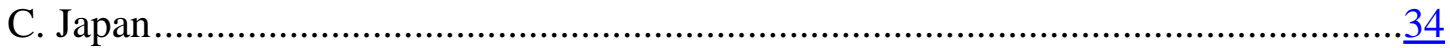

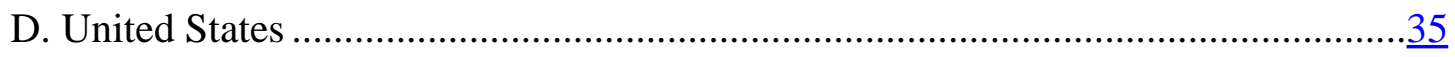

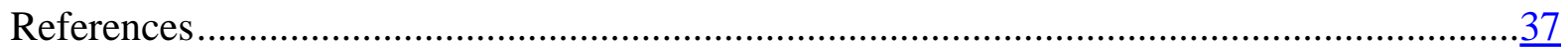

Tables

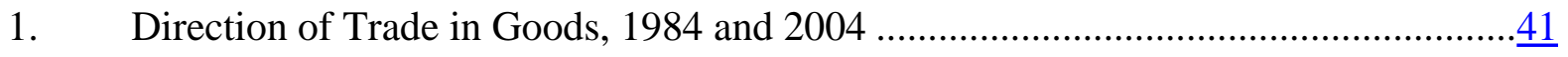

2. Evolution of Net Foreign Assets, 2002-2005: Underlying Factors 2002-2005..........42

3. Capital Gains on External Portfolios in the Euro Area and

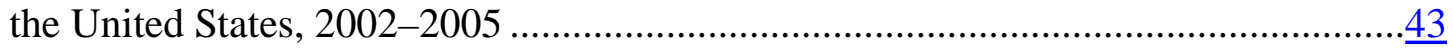

4. Currency Composition of Net External Position, 2005 ...........................................44

5. $\quad$ Net Foreign Assets and Capital Gains, Adjustment Scenarios:

Effects of Exchange Rates and Assets Prices …...................................................45

6a. European Countries: Bilateral Trade Patterns, 2004...............................................46

6b. Trade Weights in Multilateral Real Exchange Rates ..............................................

7. Net Dollar Exposures ............................................................................ 
8. Impact of 'Disruptive’ Dollar Shock ................................................................. 49

9. Current Account and Net Foreign Assets, 2005 .................................................. 50

Appendix Table

$1 \quad$ Assumptions on the Composition of Capital Flows (2006-2015).............................51

\section{Figures}

1. Current Account Balances, Major Regions, 1997-2005 ..........................................52

2. Current Account Balances: Europe versus the United States ...................................53

3. Current Account: Aggregate Balance of Europe, Japan, and United States .................54

4. Net Foreign Asset Positions: Europe and the United States ....................................55

5. The International Financial Integration of Europe.............................................56

6. Adjustment of Global Imbalances ....................................................................57

7. Europe's Current Account Balances ..................................................................58

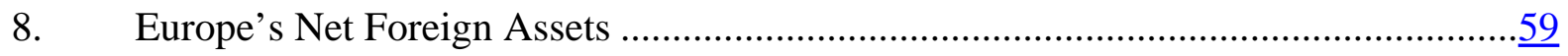




\section{INTRODUCTION}

Economic globalization has been one of the major trends shaping the world economy in recent years. On the real side, international trade has expanded substantially, with the emerging Asian countries in general, and China in particular, taking a prominent role. On the financial side, international capital flows have increased even more rapidly than product trade, leading to a remarkable rise in cross-border holdings of assets and liabilities. These developments imply tighter real and financial linkages across countries and regions, with attendant implications for the transmission of shocks and co-movements in macroeconomic variables.

Increased international trade and capital mobility have the potential to provide economic benefits through a more efficient international allocation of production and capital and greater cross-border risk diversification. They may also have facilitated the financing of larger and more persistent current account imbalances-more specifically, unprecedented U.S. trade and current account deficits and sizable surpluses in emerging Asia and oil exporters. While there is a lively debate on how long trade and current account imbalances of this size can persist, it is clear that a potential sharp correction of such imbalances is a source of risk that, in an era of financial globalization, stretches beyond those countries that must reduce external gaps and also extend to those countries that are linked through trade and finance to the adjusting economies. Accordingly, our goal in this paper is to assess the potential impact on Europe of a reduction in external imbalances across the world's major economic regions.

Although the euro area — and Europe, taken in the aggregate-are in approximate external balance, a reduction in global current account imbalances could still have a major impact on the European economy. A contraction in the U.S. deficit and the surpluses run by Asia and oil exporters would involve a shift in the global distribution of expenditure, with attendant implications for exchange rates and the level and composition of production in the major economic regions. European economies will be affected by these external developments through an array of trade and financial linkages, with potential implications for macroeconomic policy, especially in the event of a sudden movement in the external environment.

To focus our analysis, we examine a range of alternative scenarios by which global current account adjustment may take place. We consider three alternatives: a 'soft landing' scenario in which trade and current account imbalances are reduced gradually, and no major policy change occurs; a 'disruptive' scenario in which the United States ceases to attract large-scale capital inflows at a low interest rate; and a 'policy action' scenario in which adjustment is facilitated by policy changes in the major economic regions. We explore these scenarios using the Global Economic Model (GEM), a micro-founded dynamic general equilibrium model of the world economy developed at the International Monetary Fund. 
A particular innovation in our contribution is to analyze the role of both trade and financial linkages in the adjustment process. The acceleration of financial globalization in recent years means that gross holdings of external assets and liabilities are now much larger than in previous adjustment episodes, such as the turnaround in the U.S. current account deficit in the late 1980s. In turn, as pointed out in a number of recent contributions, this implies that changes in exchange rates and asset prices will have significant repercussions on the value of countries' external assets and liabilities (the so-called "valuation effects"), in addition to the effects operating through the trade balance and current account.

From a European perspective, the increase in holdings of foreign assets and liabilities in recent years means that the transmission mechanism by which external adjustment in the U.S. affects Europe has changed. In particular, in addition to trade linkages and net capital flows, the balance sheets of European firms, governments, and households will be affected by the changes in exchange rates and asset prices that are likely to accompany the adjustment process. In light of the fact that scenarios involving a narrowing in the U.S. trade deficit are characterized by a depreciation of the U.S. dollar in real effective terms, we quantify the net dollar exposure of the major economic regions and provide estimates of the implications of dollar adjustment for the value of their external holdings.

After considering the implications of external adjustment for Europe as a whole, and the euro area in particular, we turn our focus to individual European national economies. In particular, we seek to ascertain which economies may be most affected by changes in international trade patterns and in international financial markets that may accompany current account adjustment. To do so, we examine differences across the individual national economies in their trade and financial linkages vis-à-vis the United States, as well as in their external positions: while aggregate Europe is in broad balance, some national economies are running deficits that are proportionally bigger than the U.S. deficit, while others are major surplus countries.

The main findings of our analysis are as follows. First, there has been a shift in the pattern of co-movement between the U.S. and European external positions. While European and American current account balances have historically been negatively correlated, the correlation has been positive over the last decade-with the U.S. deficit largely financed by Asia and, in recent years, the oil-exporting nations. On the other hand, the negative comovement between the net foreign asset positions of Europe and the United States has become stronger over the last decade, reflecting the increased importance of the valuation channel and the financial impact of currency movements.

Second, the weakening of the U.S. dollar likely to accompany a reduction in the U.S. trade deficit would have a non-negligible negative wealth effect on European investors, by reducing the value of their dollar-denominated claims. However, this effect would likely be smaller than in China and Japan, that hold larger net dollar positions. Third, there is considerable heterogeneity across Europe (and within the euro area) both in terms of net 
positions and bilateral financial holdings in the United States. Accordingly, to the extent that a contraction in global imbalances accompanied by a shift in the global financial environment (e.g. an increase in global interest rates) and in U.S.-specific asset and currency values, this may have differential wealth and cyclical effects across Europe.

This work relates to several recent contributions on the international adjustment process. ${ }^{2}$ On the empirical side, Lane and Milesi-Ferretti (2001; 2005; 2006; 2007b) have shown the importance of valuation effects in explaining the evolution of net foreign asset positions for a large number of countries. In relation to the United States, Gourinchas and Rey (2005) have highlighted the role played by the valuation channel in stabilizing the external position, while Tille (2003) and Gourinchas and Rey (2007) have developed a detailed sectoral decomposition of the sources of valuation effects. A particularly valuable contribution for our purposes is Tille (2005), who constructs estimates of the currency composition of the international balance sheet of the United States.

In terms of theoretical contributions, our model simulations closely follow Faruqee, Laxton, Muir, and Pesenti (2007). Obstfeld and Rogoff (2000, 2005, 2007) have developed a simple analytical framework that allows them to quantify the scale of exchange rate adjustment associated with a closing of current account balances. Of these, Obstfeld and Rogoff (2005) is the closest to our own work in specifying a three-region model of the world economy and allowing for the operation of the valuation channel. Cavallo and Tille (2006) have extended this contribution by allowing for gradual adjustment in the external account, with the pace of current account adjustment influenced by valuation dynamics. Blanchard, Giavazzi and Sa (2005) also incorporate the valuation channel in a portfolio-balance model that allows for imperfect substitutability of assets across countries.

The structure of the rest of the paper is as follows. Section II describes the evolution of global current account balances and net foreign asset positions in recent years, with special attention paid to the co-movements between the European and U.S. external positions. In addition, it documents the scale and pattern of international trade and financial integration, highlighting in particular the bilateral linkages between Europe and the United States. Section III reports results from a number of adjustment scenarios produced by the GEM, which include a correction for the role played by the valuation channel. The impact of heterogeneity across individual European economies in section IV. Finally, we discuss the options available to policymakers in minimizing the risk of a hard-landing scenario and offer some conclusions in Section V.

\footnotetext{
${ }^{2}$ The 2006 report by the European Economic Advisory Group provides an excellent overview.
} 


\section{EUROPE'S EXTERNAL POSITION IN A GLOBAL CONTEXT}

In this section we consider the evolution of the current account balance of European countries taken as a group, as they relate to global trends, as well as the degree of trade and financial integration of Europe with the rest of the world in general, and the United States in particular.

\section{A. Current Account Balances: Stylized Facts}

The much-debated topic of global current account imbalances is usefully summarized by Figure 1, which plots the current account balances of Europe and the United States together with those of countries/regions that are running significant current account surpluses. Current account balances are expressed in relation to world GDP, so as to provide a perspective on their global relevance. The Figure shows that surpluses in emerging Asia, Japan, and more recently oil exporters have been the main counterpart to the widening U.S. current account deficit. In contrast, there has been broad balance in the current account of Europe (and the euro area) throughout the period.

In order to understand the likelihood that these trends will continue and the possible consequences of their reversal, it is useful to relate them to the evolution of current account balances over a longer time period, focusing more specifically on Europe and the United States. Accordingly, Figure 2 plots the current account and net foreign asset positions over 1970-2006 for aggregate Europe (with the euro area also shown) and the United States, scaled by their respective GDP levels. Over the entire period, there is clearly a negative comovement between the current accounts of the two regions; this is especially clear during the mid-1980s, when the European current account surplus grew in mirror image to the deterioration of the U.S. external balance, reflecting in particular the sizable current account surplus in Germany. However, the last decade has seen a noticeable shift-the late 1990s saw the United States and Europe simultaneously undergo a deterioration in the current account balance, with positive co-movement also seen during the 2001 growth slowdown and again in 2005-06. While the correlation in current account balances was -0.68 during 1970-1995, it has been positive at 0.40 during 1996-2006 — a striking reversal.

Figure 3 provides an additional perspective by charting the current account balance of the aggregate of the United States and Europe. It shows that the collective deficit has never been as large as the current value-around 3 percent of GDP in 2006, twice as much as in the mid1980s - reflecting the large deficit in the United States. Adding Japan to the picture does not change the main message, despite the strong negative co-movement between its current account balance and the one of the United States. Namely, the combined current account 
balance of Europe, Japan, and the United States was close to balance in the mid-1980s and shows a significant deficit today. ${ }^{3}$

We turn now to the implications of these trends in current account balances for the creditor and debtor position of Europe and the United States. Current account surpluses imply net capital outflows - purchases of foreign assets by domestic residents, including the Central Bank, exceed foreign residents’ purchases of domestic assets. Hence countries running surpluses should see an improvement in their net external position and countries running deficits should see a worsening. Figure 4 plots the net external asset positions of Europe and the United States. In light of the current account developments depicted in Figures 1 and 2, one feature is particularly striking — namely, during 2002-2005 the net foreign asset position of Europe deteriorated and the position of the United States improved slightly, despite the fact that Europe ran current account surpluses and the United States ran deficits. It is well known that exchange rate and asset price changes cause fluctuations in the value of external assets and liabilities — the so-called valuation effects - which are unrelated to the underlying current account developments. ${ }^{4}$ Hence Figures 1 and 4, taken together, suggest that these valuation effects have been moving in opposite directions for Europe and the United States. Indeed, the change in the bilateral euro/dollar exchange rate since early 2002 has been very significant. In sub-section $\mathrm{C}$, we look more closely at the factors underlying these valuation effects by documenting the evolution of Europe's degree of international financial integration with the world economy in general, and the United States in particular, and reviewing the role of the valuation channel in driving the dynamics of net foreign asset positions in recent years.

\section{B. Trade Linkages}

The extent of trade between countries is an important indicator of the extent of international interdependence: all else equal, a country is more exposed to a shock in some partner country, the greater is the extent of trade linkages between the countries. Accordingly, in this sub-section, we briefly discuss the extent of trade integration between Europe, the United States, and the rest of the world.

Table 1 shows the volumes of bilateral trade in goods (as a ratio to the GDP of the 'home' country or region) in 1984 and 2004 (comparable data on services in unfortunately not available). Aggregate trade volumes have generally increased in the last two decades, the

\footnotetext{
${ }^{3}$ See Faruqee (2004) for a related discussion. The current account balance in Japan has historically shown a strong positive co-movement with the European current account balance, which has disappeared over the past decade, while the negative co-movement with the U.S. current account balance has persisted.
}

\footnotetext{
${ }^{4}$ The current account balance includes investment income earned on assets and paid out on liabilities, but not changes in the value of assets and liabilities due to asset price fluctuations. See for example, Lane and MilesiFerretti (2005a, b) and Gourinchas and Rey (2005a).
} 
most striking development being the growth in trade with emerging Asia. For the euro area, direct trade with the United States is relatively small and — scaled by GDP-has not increased much over the past 20 years. Indeed, emerging Asia is now as important a trading partner as the United States for the euro area, despite being only $1 / 3$ the size of the United States. (Similarly, Europe and emerging Asia are broadly similar in importance as trading partners for the United States.)

Accordingly, the direct macroeconomic impact on Europe of a slowdown in the United States (or a switch in expenditures away from imports towards domestically-produced goods) through the trade channel is necessarily limited in magnitude, even if this would certainly be a significant shock for the European traded goods' sector.

However, bilateral trade volumes understate the full impact of the trade channel-U.S. and European firms compete in third markets and an expansion in U.S. exports triggered by a dollar depreciation would pose a competitive threat to European exporters. ${ }^{5}$ In addition, the impact on trade flows of a strengthening of the euro vis-à-vis the dollar would depend on what happens to the euro's real effective exchange rate. In particular, the impact of dollar depreciation on Europe will depend on whether the currencies of China and other countries in emerging Asia (as well as oil exporters) strengthen against the dollar. We will return to this issue in the next section when we describe the model scenarios.

The table also highlights how important trade links with the United States (as well as with Japan and Europe) are for the emerging Asia region, in relation to its GDP. Therefore, as discussed in Eichengreen and Park (2006), the direct effect of a decline in U.S. demand for imports would_-ceteris paribus — be felt much more strongly in emerging Asia than for Europe.

\section{Financial Linkages}

Financial linkages represent a second key form of macroeconomic interdependence. Along one dimension, an important form of financial interdependence is provided by co-movements in asset pricing, where shifts in financial returns in one region influence financial returns in other regions. Here, we focus on the extent of cross-border holdings of assets and liabilities - if domestic investors are net holders of an asset or currency issued by another country, they will be directly affected by shifts in the value of that asset or currency. ${ }^{6}$ Accordingly, as shown in the accounting framework presented in Appendix 1, the volume of

\footnotetext{
5 The weight of the United States in the IMF's real effective exchange rate index of the euro area, which takes into account third-market effects, is around 20 percent, equal to the aggregate weight of Switzerland and the United Kingdom. See Bayoumi, Lee, and Jayanthi (2005).

${ }^{6}$ See Lane and Milesi-Ferretti (2003) on the rationale for using this ratio as a volume-based indicator of international financial integration.
} 
cross-border holdings is an important indicator of the importance of exchange rate and asset price changes for the value of countries’ net external position.

Figure 5 plots the level of cross-border assets and liabilities (expressed as a ratio to GDP) for the aggregate European economy over 1984-2004 (which includes intra-European crossholdings) on the left scale; in addition, it shows the evolution of the level of bilateral assets and liabilities between Europe and United States on the right scale. The figure confirms that financial globalization has grown rapidly - the ratio of foreign assets and liabilities to GDP has grown by a factor of 3.5 over 1984-2004 (from 130 percent to over 450 percent). The figure also shows that the bilateral financial position vis-à-vis the United States has grown at only a marginally slower pace. This suggests that the importance for the wealth of European investors of movements in the value of U.S. assets and the dollar against European currencies has grown sharply over this period.?

In terms of the overall international investment position, the United States accounted for only 17 percent of the aggregate cross-border holdings of Europe in 2004, reflecting the predominance of intra-European cross-holdings in the total. However, the United States is by far the most important extra-European destination for European investors: for instance, according to ECB data, it accounted in 2005 for 36 percent of the foreign equity holdings of euro area investors and 32 percent of the foreign bond holdings (the shares for FDI and other investment are lower at 21 percent and 14 percent respectively).

In summary, then, the United States is the major extra-European destination for outward investment from Europe, with the scale of the engagement growing rapidly over the last two decades. These financial linkages provide a potentially important transmission mechanism by which fluctuations in financial returns in the United States affect the wealth of European investors - we probe the role of such valuation shocks in the international adjustment process in the next subsection and in subsection III.D below.

\section{The Dynamics of Net Foreign Asset Positions: A Decomposition}

In the preceding discussion, we have highlighted that the evolution of net external positions depends not only on whether the country is accumulating net external assets or liabilities through current account surpluses or deficits, but also on changes in the value of its external portfolio driven by valuation effects. As is shown in the accounting framework laid out in Appendix 1, the change in the ratio of net foreign assets to GDP can be decomposed into several factors: the trade balance, net investment income, net capital gains (valuation effects),

\footnotetext{
${ }^{7}$ The data underlying this figure are based on the geographical distribution of foreign assets and liabilities. As we will emphasize in the next section, there is an important distinction between the geography of international investment and its currency composition - in particular, the importance of the dollar is not exactly equal to the scale of investment in the United States. Martin and Rey $(2000,2004)$ provide a theoretical framework to understand the geographical allocation of portfolio investment.
} 
the effects of growth (since GDP is in the denominator of the ratio) and, finally, capital account transfers and errors and omissions. Table 2 provides such a decomposition of the changes in net foreign asset positions between the end of 2001 and the end of 2005 for the United States, Japan, and the euro area.

Despite running a large cumulative trade deficit, the United States actually enjoyed a slight improvement in its ratio of net foreign asset to GDP during this period. This can be mainly attributed to large capital gains but positive net investment income (despite being a net debtor) and good economic growth were also positive contributory factors. ${ }^{8}$ In contrast, the euro area ran a cumulative trade surplus but capital losses and negative net investment income flows meant that its net liability position doubled in size during this period. Other European countries, such as Switzerland and the United Kingdom, also experienced valuation losses during this period. Finally, the Japanese net foreign asset position relative to GDP was little changed, with the sizeable current account surplus (consisting of surpluses in both the trade balance and net investment income) offset by capital losses.

Table 3 provides some clues as to the sources of these capital gains and losses for the euro area and the United States by showing the local-currency rates of capital gain (that is, capital gains divided by the initial stock of assets) in selected investment categories. ${ }^{9}$ For the euro area, capital gains on portfolio debt liabilities exceeded capital gains on portfolio debt assets - since the euro area has a negative net position in portfolio debt, this contributed to aggregate capital losses. Capital gains on FDI liabilities also exceeded capital gains on FDI assets, although the impact of this differential was attenuated by the small positive net FDI position of the euro area. Finally, capital gains on portfolio equity assets exceeded capital gains on portfolio equity liabilities. However, the euro area has a substantial negative net position in the portfolio equity category (about 7 percent of GDP), so that the net impact was negative on the overall position. In contrast, the United States enjoyed a superior capital gains differential in all investment categories. Furthermore, its long position in FDI and portfolio equity meant that high average returns in these categories fed strongly into the aggregate position.

Finally, Table 3 shows that the euro-dollar exchange rate plays an important role in determining the returns the euro area earns on its foreign assets. For instance, there is a close correspondence between the euro-denominated capital gains earned on foreign portfolio equity assets and the sum of the dollar-denominated capital gains on U.S. portfolio equity

\footnotetext{
${ }^{8}$ For a net debtor country, like the United States, faster economic growth will reduce the size of net external liabilities relative to GDP. Conversely, for creditor countries faster growth will reduce the size of their net external assets relative to GDP.

${ }^{9}$ A limitation is that the data on FDI for the euro area is calculated at book value, rather than market value, During periods of significant changes in stock market prices, this will underestimate the size of capital gains and losses in this category.
} 
liabilities and the rate of dollar-euro appreciation, reflecting the importance of portfolio equity investment by the euro area in the United States. Although the bulk of the euro area's external holdings are in other European countries, the currencies of these countries are much more stable vis-à-vis the euro - the dollar is the dominant foreign-currency exposure faced by the euro area.

\section{INTERNATIONAL ADJUSTMENT}

In the previous section we have highlighted a number of stylized facts concerning the evolution of global current account imbalances and international financial integration. In particular, we have highlighted that Europe in the aggregate has a broadly balanced current account position, and - relative to its GDP - trades less with the United States than other regions of the world (particularly emerging Asia). We have also highlighted that financial linkages between Europe and the United States have grown substantially over the past two decades, and may therefore amplify the transmission of shocks from one region to the other. In this section, we take a general equilibrium perspective and discuss how a change in the pattern of global current account imbalances-and its attendant implications for macroeconomic variables, including exchange rates-may affect the European economy.

While there is considerable debate on the extent to which the current pattern of global trade and current account imbalances in general, and the United States current account deficit in particular, should be cause for concern, there is little doubt that the United States cannot run a trade deficit of 6 percent of GDP forever, and that the adjustment process is likely to entail a realignment in international relative prices. However, views differ on many other aspects of the adjustment process, including the likelihood that the current pattern of international borrowing and lending could continue for a while, the risks of a costly adjustment, the magnitude of the needed adjustment in exchange rates, and the 'trigger' for the adjustment.

For example, it is possible to envisage a "soft-landing" scenario where the United States continues to experience substantial net capital inflows, trade and current account imbalances are slowly reduced, factors are gradually reallocated from the non-traded to the traded sector in a smooth fashion, and exchange rate adjustment also occurs gradually. Such a scenario need not involve any persistent deviation from potential output, with the gradual shift in the composition of demand mirrored by the required inter-sectoral reallocation of capital and labor. At the other extreme, a "hard-landing” scenario-possibly triggered by a shift in investors’ preferences away from U.S. assets - could involve a more rapid unwinding of current imbalances, accompanied by significant swings in exchange rates with possible disruptive effects on financial markets and economic activity.

At a qualitative level, the implications for Europe of these scenarios are well understood. An appreciation of the euro against the dollar would reduce the competitiveness of European exporters vis-à-vis U.S. firms in global markets, while a growth slowdown in the United States would lower external demand for European exports. As for financial market variables, 
a decline in U.S. asset values and the dollar would reduce the value of European investment positions in the United States. In the short run, the ensuing contractionary impact on domestic output of these developments could be offset by a compensatory increase in domestic demand and/or by an increase in external demand from other parts of the world. In this regard, measures to support domestic demand and raise the level of potential output are heavily debated in policy circles, with a weakening of the euro vis-à-vis Asian currencies in real terms also perceived as an important part of the adjustment process.

\section{A. Unwinding of Global Imbalances-A Model-Based Perspective}

To provide a quantitative perspective on an unwinding of global imbalances, we present adjustment scenarios based on the IMF's Global Economic Model (GEM), a state-of-the-art multi-country dynamic stochastic general equilibrium model. We then integrate this analysis, which does not explicitly allow for valuation effects, with simulations capturing the extent to which the exchange rate adjustments predicted by the model affect the external position of countries. In particular, we focus on three possible scenarios featuring a reduction in the U.S. current account deficit, which span some of the views discussed in the literature and alluded to in the previous sub-section.

- The first is a 'benign' scenario in which an increase in the U.S. private saving rate gradually reduces the U.S. trade and current account deficits. The mirror image of the slow adjustment in the U.S. current account is the willingness of other countries to continue to purchase U.S. assets.

- $\quad$ The second is a disruptive scenario, characterized by a decline in the level of competition worldwide and a sudden decline in foreigners' willingness to hold U.S. assets, with large changes in exchange rates and a significant output decline in the short run.

- $\quad$ The third scenario features instead joint policy action by the major 'players,' designed to facilitate the reduction in global imbalances and supporting growth.

The interested reader will find a detailed technical description of model and scenarios in Faruqee, Laxton, Muir, and Pesenti (2007).

\section{B. A Brief Description of the Model}

The model has four regions: the United States; the euro area and Japan; Emerging Asian economies; and the rest of the world. ${ }^{10}$ Each region produces both tradable and nontradable

${ }^{10}$ Disaggregating the euro area and Japan would of course be a desirable but computationally very complex extension. This issue is further discussed below. Faruqee (2004) discusses scenarios of global current account adjustment using an earlier three-region version of GEM calibrated on the United States, the euro area, and the rest of the world. 
goods using capital, labor, and intermediate inputs, with constant elasticity of substitution production functions. Bilateral trade flows take place between the blocks-relevant share parameters are calibrated so as to ensure that the model broadly replicates actual trade flows among the major areas. Goods and labor markets are imperfectly competitive and subject to nominal rigidities. There are two types of consumers: liquidity-constrained ones that consume their disposable income, and forward-looking consumers that are non-Ricardianthat is, they treat a portion of government debt as net wealth. The model also includes an array of adjustment costs in consumption and labor supply (habit persistence), investment, and the composition of trade so as to ensure that it reasonably matches data properties at business-cycle frequencies.

Monetary policy in the United States, the Japan-euro area block, and the rest of the world is characterized by an interest rate feedback rule à la Taylor that gradually moves inflation toward to a constant desired rate. In the first scenario, monetary policy in emerging Asia is geared towards maintaining a fixed exchange rate vis-à-vis the dollar. In the other scenarios emerging Asia is assumed to abandon the exchange rate peg and adopt a monetary policy rule similar to the one in the other regions. In all countries, fiscal policy is aimed at stabilizing the debt-to-GDP ratio over the medium term.

There is free capital mobility between regions, with one international bond being traded internationally. The interest rate parity condition is augmented by a country-specific risk premium, whose size depends on the difference between actual and desired net foreign assets. Therefore, desired holdings of net foreign assets (or foreign liabilities) in each region over the medium term play a key role in determining the equilibrium level of current account balances and exchange rates. In the long run, motivated by assumptions about demography and productivity differences, the United States is assumed to be the only debtor region, with the remaining regions holding positive net foreign assets. The model features a decline in the medium-term rate of productivity growth in emerging Asia, as its income level approaches the one in more advanced economies, and a decline in output growth in Japan and the euro area, reflecting demographic trends.

In the model, the current set of imbalances are assumed to reflect primarily saving behavior by both the private and public sector, rather than investment dynamics fueled by (excessively) optimistic productivity and growth expectations as in the second half of the 1990s. More specifically, the two main driving forces behind the current account dynamics are temporarily low private and public savings in the United States, together with a portfolio preference shock generating strong demand for U.S. assets abroad, particularly in Emerging Asia. Both contribute to the U.S. current account deficit, the latter by reducing the rate of return required by foreigners in order to hold U.S. assets. ${ }^{11}$

\footnotetext{
${ }^{11}$ Hunt and Rebucci (2003) discuss the role of this channel in explaining the emergence of the U.S. current account deficit. This 'risk premium' in other smaller and less-developed countries typically rises as net external
} 
Clearly parameter values play an important role in shaping the response of the world economy to the various shocks. While we refer the reader to Faruqee et al. (2005) for details on model parametrization, we highlight here two parameter values that help interpret the quantitative features of the model.

- The first key parameter is the elasticity of substitution between domestically-produced and foreign-produced traded goods, which influences the extent of relative price adjustment necessary to induce a change in the relative consumption of these goods. In line with the calibration of most large macroeconomic models, this elasticity is chosen to be 2.5-a value which is higher than the one that would be consistent with macroeconomic evidence on the response of imports and exports to real exchange rate fluctuations (albeit lower than the one that microeconomic estimates of responses of trade to relative prices suggest). ${ }^{12}$ As a result, the adjustment in real effective exchange rates associated with reduced external current account imbalances is generally smaller relative to other model-generated estimates in the literature (such as, for example, Blanchard, Giavazzi, and Sa (2005), Obstfeld and Rogoff (2005, 2007), and Krugman (2007)). ${ }^{13}$

- The second parameter captures the extent of "non-Ricardian" behavior-that is, the extent to which consumers that are forward-looking treat their holdings of public debt as net wealth. In line with results obtained from a calibration of a finite-horizon DSGE model (Kumhof, Laxton, and Muir, 2005) the long-run relation between public debt and the net external position (and hence between the current account and the fiscal balance) is such that a permanent 1 percentage point increase in public debt reduces desired net foreign assets by $1 / 2$ percentage point in the long run. Other open-economy DSGE models (see, for example, Erceg, Guerrieri, and Gust, 2005) do not incorporate any long-run relation between public debt and the external position, and imply a smaller "offset" $(0.1$ to 0.2 ) over the medium term.

Finally, it is important to stress a few other limitations of the model. First, the model has a rich "real" structure and a realistic role for monetary policy, but a very stylized structure of international financial flows, with only one internationally-traded bond and hence no room for capturing the effects of exchange rate and asset price changes on gross external positions. We address this issue later in the Section. Second, for the purpose of interpreting the results for Europe, the model aggregation is not ideal in that the euro area is considered together with Japan, while the rest of Europe constitutes part of the very heterogeneous rest of the world block. The choice of aggregating the euro area and Japan reflects the fact that both

liabilities accumulate, acting as a brake on the size and persistence of current account deficits.

${ }^{12}$ Obstfeld and Rogoff (2005a) discuss alternative parametrizations of this elasticity of substitution.

${ }^{13}$ An exception is the study by Engel and Rogers (2006). 
regions are experiencing slow growth relative to their historical averages, face similar demographic pressures, and have floating exchange rates. Also, as mentioned in Section II, the dynamics of the current account balances of Europe and Japan have historically being strongly positively correlated. A "de facto" disaggregation is undertaken in the exercise on valuation effects that follow.

\section{Model-Based Adjustment Scenarios}

As mentioned earlier, the U.S. trade deficit-currently 6 percent of GDP — has to eventually decline to ensure that U.S. net external liabilities do not grow without bounds. Analogously, the large trade surpluses of Asian economies and oil exporters have to shrink to ensure that their external assets eventually stabilize as a ratio of GDP. We focus on three possible adjustment scenarios (also described in IMF 2005b, 2006).

- $\quad$ The first, baseline scenario sees little change in economic policy across regions. Monetary policy is anchored by a Taylor rule aimed at stabilizing inflation except—as mentioned earlier - in emerging Asia, where the exchange rate is pegged to the U.S. dollar. Fiscal policy stabilizes the debt to GDP ratio. There is a gradual increase in U.S. private saving, entailing a slow reduction in the U.S. current account deficit.

- The second, “disruptive” scenario features instead a sharp decline in other countries' willingness to hold U.S. assets and an abandonment of emerging Asia's peg to the dollar, with the resulting abrupt exchange rate realignments temporarily reducing global competition pressures (higher price and wage markups). Monetary policy responds to these inflationary pressures, and the combined effect of shocks and policy responses causes a generalized decline in output relative to trend in all regions of the world.

- Finally, the third scenario is characterized by the implementation of a set of policies designed to reduce imbalances and stave off the risks of a disorderly adjustment. In emerging Asia, there is a shift towards a flexible exchange rate regime, with monetary policy following a Taylor rule similar to the one in other region. The ensuing decline in the accumulation of reserves is assumed to reflect a decline in the desired stock of longrun net foreign assets, and hence entails an increase in private consumption. Finally, there is a modest increase in productivity assumed to be driven by financial sector reform. In the United States, there is a reduction in the U.S. budget deficit from 4 percent of GDP in the baseline to broad balance by 2011. ${ }^{14}$ In the euro area and Japan, structural reforms are assumed to raise productivity and growth by lowering mark-ups in both labor and product markets, thereby reducing precautionary savings. Finally, a boost to consumption and investment is assumed to take place in oil exporters, as their

\footnotetext{
${ }^{14}$ The budget deficit is assumed to subsequently widen to some extent, driven by demographic trends.
} 
infrastructure is upgraded and consumption reflects the improvement in the terms of trade.

Figure 6 summarizes the main features of the three scenarios, focusing on the United States, emerging Asia, and the Japan/euro area block. It displays the behavior of output growth, the current account, net foreign assets, and the real effective exchange rate, defined as the ratio of trading partners' price levels to the domestic price level (so that an increase implies a real depreciation).

\section{Baseline scenario}

In this scenario (represented by the blue line in Figure 6), the negative shock to U.S. private savings unwinds slowly, leading to a gradual reduction in the U.S. trade and current account deficits. The slow current account adjustment implies a substantial accumulation of external liabilities by the United States, which reach 50 percent of GDP by 2015 and over 80 percent in the very long run, matched by the accumulation of external assets elsewhere, particularly in emerging Asia and in the euro area-Japan bloc. The slow trade balance adjustment is accompanied by a gradual depreciation of the dollar vis-à-vis all trading partners, of over 15 percent in real effective terms over the long run. In emerging Asia, because of the exchange rate peg, real effective appreciation occurs through a positive inflation differential vis-à-vis other countries. ${ }^{15}$

\section{Disruptive scenario}

This scenario, depicted by the red line in Figure 6, is characterized by a sharp reversal of the portfolio preference for U.S. assets, an abandonment of emerging Asia's peg to the dollar that results in an abrupt exchange rate realignment, and reduced global competitive pressures. The latter effect, akin to the worldwide adoption of protectionist measures, is proxied in the model by an increase in margins (a decline in product market competition) in all regions of the world. ${ }^{16}$ As a result of these shocks, the dollar falls very sharply vis-à-vis all currencies, but particularly so vis-à-vis the currencies in emerging Asia. ${ }^{17}$ The dollar depreciation is

\footnotetext{
${ }^{15}$ The model has no room for effective sterilized exchange rate intervention, which would delay real exchange rate adjustment. Consequently, this adjustment in emerging Asia is relatively rapid, despite the exchange rate peg. See also Faruqee et al (2006) on the macroeconomic impact of a protectionist response to global imbalances.

${ }^{16}$ For example, the abandonment of the dollar peg by emerging Asia may imply the disappearance of a factor which has increased competition in the traded goods' sector and thus helped keep inflation low.

${ }^{17}$ Using a portfolio balance model, Blanchard, Giavazzi, and Sa (2005) highlight that if China abandons a dollar peg, the yen and the euro would appreciate vis-à-vis the dollar, because the market loses an investor with 'extreme' dollar preference. Of course, the bilateral euro appreciation need not imply a real effective appreciation. Obstfeld and Rogoff (2005) consider a disruptive scenario in which Asia maintains its dollar peg, which implies a much larger bilateral appreciation of the euro against the dollar.
} 
driven by the decline in demand for U.S. assets, and the adjustment of the U.S. current account is very abrupt. Correspondingly, the current accounts in other regions of the world worsen. De facto, the adjustment process is "collapsed" in a very short period, and hence more disruptive. In terms of output performance, the disruptive effects are enhanced by reduced competition, which generates inflationary pressures, causing an increase in interest rates and a generalized decline in activity in all regions.

\section{“Policies" scenario}

In addition to the gradual "baseline” unwinding of imbalances generated by rising U.S. private saving, this scenario envisages the implementation of a series of policy measures which broadly reflect those outlined in several G-7 and IMFC Communiqués. These policies include: (i) a substantial reduction in the U.S. budget deficit, from 4 percent of GDP (the baseline level) to broad balance excluding social security by early in the next decade; (ii) increased exchange rate flexibility and measures raising private consumption in emerging Asia, (iii) growth-enhancing structural reforms in the euro area and Japan, and (iv) a boost to investment in oil exporters. ${ }^{18}$

In this scenario, depicted by the green line in Figure 6, the U.S. current account adjusts more rapidly, since all policy actions go in the direction of reducing U.S. net external borrowing. The corresponding exchange rate adjustment is more rapid in emerging Asia, where the abandonment of the peg implies a quicker real appreciation, occurring through a shift in the nominal exchange rate rather than through inflation as in the baseline. While world growth declines in the short run, reflecting the initially contractionary effects of fiscal adjustment in the United States, it is higher over the medium term, thanks to higher growth in Japan and the euro area and the lower interest rates associated with a declining U.S. public debt.

Clearly, not all policies have the same impact on the U.S. current account deficit. The most significant impact comes from U.S. fiscal policy - a 1 percent of GDP reduction in the budget deficit improves the current account balance by $1 / 2$ percent of GDP over the medium term, and hence accounts for almost half of the total U.S. current account adjustment relative to the baseline. The quantitative impact of structural reforms in Japan and the euro area on the U.S. current account is instead relatively modest, but plays an important role in sustaining world growth as U.S. domestic demand declines.

\footnotetext{
${ }^{18}$ Increased exchange rate flexibility in Asia is captured by assuming that the region shifts to a monetary policy rule similar to the one in other parts of the world, while the increase in private consumption is generated by an increase in consumers' "impatience." In addition, the shift in the exchange rate regime is associated with a decline in desired net foreign assets, which can be interpreted as resulting from a decline in the accumulation of reserves. Structural reforms in the euro area and Japan are assumed to lead to an increase in goods' and labor market competition, with the decline in mark-ups eliminating about two thirds of the gap with U.S. levels over a ten-year period. Also, increased productivity growth is assumed to be reflected in lower precautionary savings. Finally, increased domestic demand in oil exporters is generated by an investment shock (triggered by higher productivity) as well as higher consumption.
} 


\section{Implications for the euro area}

The euro area represents over two thirds of the "Japan-euro area” bloc. In terms of the small list of key variables shown in Figure 6, there are substantial differences between the Japan and the euro area in regard to current account balances (where Japan has a hefty surplus, while the euro area is in broad balance), net foreign assets (that in Japan are around 40 percent of GDP, while the euro area is a net external debtor), and recent trends in real effective exchange rates (where the euro has appreciated by around 20 percent in real effective terms between February 2002 and February 2007, while the yen has depreciated by around 17 percent during the same period).

Together, these trends would suggest that, in the scenarios depicted in Figure 6, current account adjustment and real effective exchange rate appreciation would be more substantial in Japan than in the euro area. Assumptions along those lines underpin our next exercise, which attempts to quantify the valuation effects on the external position that would be implied by the three scenarios just described.

\section{Valuation Changes}

While the scenarios presented in the previous section provide a useful perspective on some possible features of global external adjustment, they do not include the impact of currency realignments on net external positions. The main reason why the model cannot properly capture valuation effects is that it only allows for one internationally-traded bond and hence only net exposures between countries - in other words, a debtor country has only external liabilities and no external assets, while a creditor country has only external assets and no external liabilities. This limits the impact of exchange rate changes on the value of a country's assets and liabilities. For example, at end-2005 the United States net external position (excluding gold) was negative for about \$2.7 trillion. However, its net U.S. dollar position was around minus $\$ 9$ trillion, because the United States holds substantial external assets denominated in foreign currency.

We are not the first in considering how valuation effects affect external adjustment in models where the U.S. current account deficit shrinks. Blanchard, Giavazzi, and Sa (2005), Obstfeld and Rogoff (2005, 2007), and Cavallo and Tille (2006) have also considered these issues, albeit with a simpler underlying macroeconomic structure and a more stylized calibration of portfolio structure.

In order to infer the potential implications of exchange rate adjustment for the value of the external holdings in the model, we start from the currency and asset composition of the international balance sheet for the main country blocks in 2005. We then consider a set of projections for capital inflows and outflows (and their currency composition) for all scenarios, such that the net flows are equal to the model's projected current account balances. The projected flows, together with the model-based path for exchange rates, allow us to calculate the evolution of gross external assets and liabilities, and more specifically the 
impact of valuation changes on the net external position. In undertaking this exercise, we separate out projections for the euro area and Japan, both in terms of external current account adjustment and in terms of external portfolios. As mentioned earlier, we assume that the real exchange rate and current account adjustment is larger in Japan than in the euro area. We also consider China separately from the rest of emerging Asia, assuming that real exchange rate and current account adjustment in China are broadly of a similar order of magnitude as for the region as a whole.

The exposure of a country to movements in exchange rates clearly depends on the currency composition of its international balance sheet. Estimating such currency composition is a difficult exercise. This is especially true for currencies such as the dollar and the euro that are heavily employed in international financial trade, since even information about the geographical distribution of external portfolios is only of limited value when many countries issue debt denominated in these currencies. For instance, the net dollar position of the euro area is the sum of dollar assets located in the U.S. (which is not equal to the sum of total euro area assets in the U.S., since the U.S. also issues euro-denominated liabilities), plus dollar assets located elsewhere, minus the dollar liabilities issued by euro area residents to nonresidents.

Appendix 2 discusses how we estimated the currency composition of the external portfolio for the United States, the euro area, Japan, and China. The data are summarized in Table 1. It shows that all countries are short in their domestic currencies and that the euro area, Japan and China are each long in dollars (although the figures for China are subject to significant uncertainty, given the lack of data on the currency composition of its portfolio). However, Japan and China are much larger “dollar creditors" than the euro area relative to their GDP levels. This reflects their aggregate net creditor status and a portfolio composition that is more heavily weighted towards the dollar than is the case for the euro area. Finally, as already highlighted by Tille (2005), the U.S. net dollar liability position is very substantial.

An important caveat to our analysis is the lack of systematic data on cross-border hedging. Note that hedging vis-à-vis other domestic residents would only shift the risk within an economy, but would not affect its overall exposure to the rest of the world. Hau and Rey (2006) indicate that the level of hedging for portfolio equity positions is limited, and the BIS foreign exchange survey suggests that most hedging is undertaken with domestic counterparties. In addition, hedging long-term exposures is very costly. Nevertheless, to the extent that at least some of the net positions we estimate are indeed hedged, our estimation would only provide an upper bound on the valuation effects of cross-currency fluctuations. ${ }^{19}$

\footnotetext{
${ }^{19}$ Campbell et al (2006) find that the dollar is almost uncorrelated with the U.S. equity market and negatively correlated with the world equity market, suggesting that international investors may wish to hold long dollar positions as a risk-minimization strategy.
} 
Projections of capital flows and of their currency composition are necessary to keep track of valuation changes in the years following the initial shock. Recent years have seen a major increase in cross-border flows, so that external assets and liabilities have been increasing sharply in relation to GDP. We assume that this trend will continue in the future, albeit at a slower pace. Inflows and outflows of specific types - direct investment, portfolio equity, portfolio debt, other investment flows, and reserves-are assumed in most cases to remain constant as a share of GDP, broadly reflecting recent trends (Appendix Table 1). In order to ensure that net capital flows equal the model's path for the current account, we assume that for each country/block there is one residual category of flows that acts as "adjustor"-foreign exchange reserves for emerging Asia, portfolio debt assets for the euro area and Japan, and portfolio debt liabilities for the United States.

With regard to the currency composition of countries' external portfolios, we make a stark simplifying assumption-namely, that the share of each asset and liability category denominated in dollars and other currencies remains constant over time. This implies that countries fully offset the impact of valuation changes on the currency composition of their portfolio: as the dollar depreciates, for example, the currency composition of flows ensures that the dollar share of each asset and liability category remains constant. This assumption turns out to be less restrictive than it appears at first sight: in the two scenarios involving "large" currency movements in the short run, the initial currency exposure is key in determining the valuation effects, and that exposure is predetermined.

Valuation changes in the model are captured as follows. For dollar-denominated assets and liabilities, their domestic-currency value is adjusted to reflect changes in the exchange rate between the dollar and the domestic currency. In addition, for portfolio equity assets in the United States we assume that their capital value increases in line with the U.S. GDP growth rate. For the remaining foreign-currency assets, we make the following assumptions:

- For foreign direct investment and portfolio equity assets by non-U.S. countries outside the U.S., we assume that their dollar value increases in proportion to the effective depreciation of the U.S. dollar;

- For portfolio equity assets (and liabilities) we also assume capital gains in proportion to output growth in the rest of the world (for assets), and domestic output growth (for liabilities). We do not make a corresponding valuation adjustment for FDI flows in light of the fact that for FDI reinvested earnings are counted investment income (and correspondingly as new FDI) while for portfolio equity holdings retained company profits are reflected in the firm valuation, but not in investment income.

Table 5 shows the main results in terms of capital gains and losses for the various scenarios, showing both capital gains and losses induced by changes in real exchange rates as well as overall capital gains and losses (including those arising from the assumed capital gains on portfolio equity holdings). Capital gains as of 2008 and 2015 are calculated as the present 
value of the difference between the net foreign asset position and the cumulative value of the current account at that date (measured in U.S. dollars), as a ratio of 2005 GDP. The applied discount rate is 6 percent, about 1 percent higher than the current interest rate on long-term U.S. bonds.

- $\quad$ Clearly, the United States stands to gain from valuation effects in all scenarios. While exchange-rate related valuation gains are larger in the baseline, in light of the larger stock of U.S. dollar liabilities, higher growth in the policies scenario drives higher growth-induced capital gains on U.S. equity holdings overseas, and hence larger overall gains in that scenario.

- For all remaining country groups, the disruptive scenario generates the largest capital losses. These are particularly high in China and Japan, because of the scale of exchange rate appreciation as well as of net dollar exposure-in the euro area, capital losses are only about a third as high as in Asia. The assumption that capital gains made by foreigners on portfolio equity liabilities are related to the country's growth rate magnify China's total net capital losses on the external position, as can be seen by comparing total with exchange-rate-induced capital losses. ${ }^{20}$

- With regard to the euro area, exchange-rate-induced capital losses are significant but much smaller than for China and Japan. Faster growth of the euro area economy in the “policies” scenario imply larger capital gains for non-residents on euro area's equity assets, and therefore total net capital losses on the external position are larger in the policies scenario than in the baseline, although the exchange-rate-related losses are somewhat smaller.

How would these gains and losses affect the external adjustment path depicted in Figure 6? For given long-run values of net external assets and liabilities across regions, valuation gains and losses would allow regions experiencing capital gains to sustain —other things being equal-higher consumption equivalent to the annuity value of such gains, and correspondingly require higher surpluses (and hence lower consumption) to achieve desired long-run asset holdings in regions experiencing capital losses. However, the size of long-run real exchange rate adjustment would be unchanged relative to the situation without valuation effects. ${ }^{21}$ Of course, looking forward, it would be desirable to fully embed portfolio choices

\footnotetext{
${ }^{20}$ This result is crucially driven by the assumption concerning capital gains on portfolio equity as well as by the additional assumption that China accumulates portfolio equity liabilities (worth over 10 percent of GDP by 2015, compared to around 3 percent now).

${ }^{21}$ In contrast, in the exercise undertaken in Obstfeld and Rogoff (2005), valuation effects reduce the need for exchange rate adjustment. This occurs because the authors focus on the exchange rate adjustment needed to reduce the U.S. current account deficit by a given percentage of GDP. A dollar depreciation reduces the stock of U.S. net external liabilities, and therefore its debt service burden relative to GDP. This implies that the trade
}

(continued...) 
in a general equilibrium model. While this line of research is currently receiving much attention (see, for example, Devereux and Sutherland, 2007; Engel and Matsumoto, 2006; Ghironi, Lee, and Rebucci, 2007), it is still in its early days.

A final important point concerns the possibility that exchange rate adjustment will not take place as the model scenarios suggest. In particular, in all model scenarios, the real effective appreciation in emerging Asia-occurring through inflation in the baseline, and nominal appreciation in the other scenarios - is relatively rapid. ${ }^{22}$ Obstfeld and Rogoff (2005b) present a scenario where Asian countries maintain a dollar peg even as the U.S. current account shrinks and the dollar weakens. In the three-region world they consider the third region-Europe - bears the brunt of the adjustment, with a sharp appreciation of the euro as the U.S. deficit shrinks and Asia's surplus increases.

\section{Heterogeneity}

An additional factor in considering the European impact of a global correction is the heterogeneity across Europe in terms of initial conditions and exposure to a correction in the US external imbalance. We consider three dimensions of heterogeneity: first, differences in trade patterns; second, different financial exposures to movements in the dollar and US asset prices; and, third, differences in external positions.

\section{A. The Trade Channel}

Table 3a shows that intra-European trade constitutes the lion's share of total international transactions for European countries. The level of direct trade with the United States and East Asia is relatively low in most cases, the main exception being the high level of trade between Ireland and the United States. In addition, the data show that the United States and East Asia are broadly similar in importance as trading partners for most European countries (although, of course, the sectoral composition of trade is likely to be very different across these two regions.). Accordingly, the direct impact of a slowdown (or a switch in expenditures away from imports towards domestically-produced goods) in the United States on individual European countries through the trade channel is limited in magnitude. Moreover, a redistribution in spending from the United States to East Asia (as in benign adjustment scenarios) would have a roughly neutral aggregate impact, with rising trade with East Asia compensating for a decline in trade with the United States.

However, the scale of direct trade is an incomplete measure, since European firms may compete with American firms for market share in common third markets. For this reason, it

balance adjustment necessary to achieve the needed reduction in the current account deficit is smaller, and hence the needed dollar depreciation is smaller.

${ }^{22}$ Technically, this occurs in the baseline because the model does not have scope for sterilized intervention. 
is also informative to take into account such third-country effects in quantifying the importance of the trade channel. Accordingly, Table 3b shows the weight of the United States in the multilateral real exchange rates for various European countries. The trade weights used are so-called double export weights, in order to capture not only competition in the domestic markets of the various competitors but also competition in export markets elsewhere. The bilateral exchange rates between the currency of a given country and the currencies of its competitor countries are weighted according to the competitors' share in the total supply of competing goods (including the supply by domestic producers) in each market separately and the relative share of each market in the total exports of the given country.

The results in Table 3b largely back up the data on trade volumes in Table 3a: while the United States has a high trade weight for Ireland and the United Kingdom, its weight is typically less than 10 percent for most European countries. Similarly, it is again the case that East Asia is comparable in importance to the United States in relation to trade weights.

Overall, the message from Tables 3a-3b is that the trade channel is only of limited importance for most European countries-however, it poses a particular vulnerability for Ireland and, to a lesser extent, the United Kingdom. Moreover, scenarios in which contraction and/or depreciation in the United States is offset by expansion and/or appreciation in Asia represents a broadly-neutral aggregate trade environment for most European countries.

\section{B. The Valuation Channel}

In Figure 6, we showed that European countries now hold much higher levels of cross-border assets and liabilities than was the case 10 or 20 years ago. As is demonstrated in the accounting framework in Appendix 1, this means that shifts in the rates of return earned on foreign assets and paid out on foreign liabilities are an increasingly important source of movements in net foreign asset positions and generate cross-border wealth effects. In this subsection, we examine the impact on European wealth of a decline in U.S. asset markets and a depreciation in the dollar against European currencies.

Table 7 shows the estimated net dollar positions for individual European economies in the various investment categories. Our method of calculating these positions largely follows the procedures employed in section III to measure the net dollar positions of the aggregate euro area, the United States, Japan, and China. In particular, the net dollar position in the FDI category is the sum of a country's FDI stock in the United States plus 50 percent of its FDI stock in offshore financial centers. Similarly, for most countries, the net dollar position in the portfolio equity category is the sum of a country's portfolio equity stock in the US plus 50 percent of its portfolio equity stock in offshore financial centers. However, for five members of the euro area-Austria, Greece, France, Italy, and Portugal-we are able to use their directly reported dollar positions in the portfolio asset category. In order to calculate net dollar exposures in the portfolio debt category for the other countries, we follow the pattern 
we observed for the aggregate euro area in the previous section by assuming that total portfolio dollar assets are 3.5 times as large as direct portfolio debt assets in the United States and that total portfolio dollar liabilities are 1.67 times as large as portfolio debt liabilities visà-vis the United States.

We also report the estimated net dollar position of the banking sectors in each European country. For most countries, we obtained these data from the websites of national central banks; otherwise, we calculated the net dollar position of the banking sector as the sum of net foreign-currency claims on the United States plus 75 percent of net foreign-currency claims on other countries. ${ }^{23}$

Finally, we add as a memo item the level of FDI liabilities vis-à-vis the United States. This is included, since one transmission mechanism that is periodically discussed is the impact of exchange rate movements on direct investment decisions, with dollar depreciation assumed to have an adverse impact on the level of American direct investment into Europe.

An important message from Table 7 is that the level of dollar exposure is relatively small for most European countries. Among the members of the euro area, three groups can be distinguished, with the group of Austria, Finland, Greece, Italy, and Portugal having a low level of dollar exposure, a second group comprising Belgium, France, and Germany having an intermediate level of exposure, while the financial centers of Ireland, Luxembourg and the Netherlands have a much higher level of exposure. ${ }^{24}$ We also highlight that the group of euro 'outs' (Denmark, Sweden and the United Kingdom) have a higher average level of dollar exposure, as do Norway and especially Switzerland. In regard to the banking sector, net dollar positions are negative for most European countries (the U.K. banking sector has an especially large short dollar position — see Elliott and Min, 2004), with the main exceptions being the long net dollar positions in Germany, Luxembourg, and Switzerland. Finally, turning to FDI liabilities vis-à-vis the United States, Ireland has by far the largest exposureU.S. FDI in Ireland amounts to 69 percent of Ireland's GDP. Among the other countries, U.S.

\footnotetext{
${ }^{23}$ We assume that the 'foreign currency' assets and liabilities of European banks in the U.S. are denominated in dollars. The 75 percent ratio for foreign currency assets and liabilities vis-à-vis other countries is based on aggregate BIS data on the currency composition of foreign-currency assets and liabilities of its reporting banks. While the assets and liabilities of banks primarily take the form of loans and deposits (part of the 'other' category in the international investment position), the banking sector is also a holder of securities, so there is some overlap with the portfolio debt and equity categories for those countries that do not provide a breakdown between loans/deposits and other instruments.

${ }^{24}$ We do not report the portfolio equity and debt positions for Ireland and Luxembourg, since these categories are heavily influenced by the presence of large mutual fund sectors that mostly cater to off-shore investors. Since shares in mutual funds are classified as portfolio equity liabilities, regardless of the investment profile of the mutual fund, these countries have large negative net equity positions and large positive net debt positions.
} 
FDI is substantial only for the euro 'outs' and the financial centers of Luxembourg and the Netherlands. ${ }^{25}$

Having established the net dollar positions of individual European economies, we consider in Table 8 the impact of an unanticipated decline in the U.S. dollar, in line with the 'disruptive' scenario laid out in Section III. Under this scenario, the dollar depreciates by about 20 percent against the euro and this depreciation persists at least out to 2015. Clearly, the information in Table 7 could be used to examine alternative shocks to the dollar and to US asset prices. For instance, Warnock (2006) considers the impact of a simultaneous 10 percent decline in the dollar and 10 percent fall in U.S. equity and bond markets on a wide range of counterpart countries, where he primarily relies on gross dollar exposures. Once again, the same caveat about the lack of information on cross-border hedging applies here.

The results in Table 8 show that all European countries experience a capital loss in event of dollar depreciation. For most countries, the loss on FDI, portfolio equity, and bond positions is about 1.5-3 percent of GDP, which is partially offset by a capital gain from the short dollar position in the banking sector. While the overall effect is the same order of magnitude as current account imbalances for these countries, the wealth effect from such a loss is minor. However, there is a group of countries that register noticeably higher capital losses: these include the Netherlands, Denmark, Sweden, Norway, the United Kingdom and Switzerland, even if capital gains in the banking sector provide a partial offset for the United Kingdom and Sweden. ${ }^{26}$

The numbers in Table 8 relate only to movements in the dollar-euro exchange rate. Under a disruptive adjustment scenario, slower economic growth and an increase in interest rates would have a negative impact on world asset prices - and particularly U.S. asset prices, since the shock involves a shift in portfolio preferences away from U.S. assets. ${ }^{27}$ This would amplify the capital losses suffered by countries with large investment positions in the United States. While asset price changes would have an additional impact on net external positions, they would have a more pronounced effect on domestic financial wealth, in light of the still strong home bias in asset holdings. From this perspective, the effects on economic activity

\footnotetext{
${ }^{25}$ The level of U.S. FDI in Luxembourg and the Netherlands is over-stated due to the role of these countries as a home for holding companies that are employed by U.S. parents to conduct direct investment in other destinations. The table does not show the level of U.S. FDI in Central and Eastern Europe-but this stock is only a small fraction of the GDP levels of these countries.

${ }^{26}$ However, the capital gains to the banking sector in the United Kingdom (and other international financial centers) will largely accrue to the foreign-owned banks that are most heavily involved in international banking transactions - that is, it may be associated with an increase in the value of the FDI liabilities of the United Kingdom and/or a larger profit outflow to the parent entities. See also Elliot and Min (2004).

${ }^{27}$ In terms of historical co-movements between asset prices and exchange rates, it is noteworthy that Campbell et al (2006) find little correlation between the dollar-euro exchange rate and the US stock market.
} 
would likely be strongest in the countries suffering the largest decline in asset prices. Indeed, the disruptive scenario described in Section III features a sharper decline in activity in the United States than elsewhere.

\section{Net External Positions}

Figures 7 and 8 show that the broad external balance of the European economy obscures significant differences in external positions across individual European countries. These differences are highlighted in Table 9, which shows the distribution of current account balances and net foreign asset positions, plus the decomposition of the latter between net equity and net debt. There is a bi-modal distribution of current account balances, with one group running sizeable surpluses (Belgium, Germany, Luxembourg, Netherlands, Norway, Sweden, and Switzerland) and another group running deficits of similar magnitude to the US deficit (Greece, Portugal, Spain and the Central and Eastern European countries). This distribution is broadly replicated for net foreign asset positions (the correlation is 0.85), highlighting the persistence of these imbalances.

In terms of exposures, these differences in external positions matter for several reasons. First, to the extent that the correction of global imbalances involves an increase in global interest rates (for instance due an increase in domestic investment in Asia and the oil producers, as in the 'policies' scenario in section III), this will have a positive impact on the financial terms of trade of countries with a positive net debt position and a corresponding negative impact on countries with a negative net debt position. Table 9 shows that there are considerable differences between aggregate net positions and net debt positions. In particular, the external liabilities of some countries primarily take the form of equity liabilities - the CEEC group provides a good illustration, with FDI the predominant form of liabilities for these countries (Lane and Milesi-Ferretti 2007a). ${ }^{28}$ Conversely, most of the advanced European countries (whether aggregate creditors or debtors) have negative net debt positions-with the typical creditor nation in effect employing leverage to build positive a net external equity position. For these countries, an increase in world interest rates raises the cost of leveraging. Aside from the financial centers of Ireland and Luxembourg, the only European countries that have positive net debt positions and would thereby enjoy a positive terms of trade effect from an increase in world interest rates are Belgium, Norway, and Switzerland.

A second possibility—related to the 'disruptive' scenario in section III —is that international investors will show increased risk aversion in relation to the currencies of those countries running significant current account deficits. In this case, it is important to differentiate between those countries that are members of the euro area (where the broad external balance of the aggregate euro area suggests that the euro would not be weakened under this scenario) and those outside the euro area (that is, the CEEC group). In particular, an increase in

\footnotetext{
${ }^{28}$ However, some CEEC countries do have significant net external foreign-currency debt (e.g. Hungary).
} 
international risk aversion may reduce capital flows to these countries, with the countries most at risk being those with significant net external debt denominated in foreign currency. ${ }^{29}$

Third, a disruptive adjustment scenario would have a negative impact on global equity values, through its negative impact on global economic growth. ${ }^{30}$ As discussed earlier, the negative wealth effect of a decline in domestic equity values would be quantitatively the most important. In addition, the advanced European economies with large net external equity positions would suffer a negative valuation effect, even for those countries with a limited net dollar exposure.

\section{Policy Discussion}

Although it is important not to over-state the scale of heterogeneous exposures across Europe, this section has indicated that differences in trade patterns, financial exposures, and net external positions mean that a disruptive adjustment in global imbalances would constitute an asymmetric shock. Adjustment to this shock may in principle require non-trivial bilateral real exchange rate movements between European countries. ${ }^{31}$ Real exchange rate adjustment between creditor and debtor members of the euro area would need to be accomplished through differential inflation rates - this would plausibly be a slow process in light of the low inflation rate in creditor countries, and may therefore be associated with more pronounced cyclical slowdowns in debtor countries, especially so if structural rigidities hinder the intersectoral reallocation of resources (see Blanchard, 2006). Outside the euro area, the other advanced European economies all have strong domestic anchors for monetary policy and can achieve bilateral adjustment vis-à-vis the euro area through nominal exchange rate movements.

Countries of Central and Eastern Europe that are running large current account deficits and do not have similarly robust domestic monetary anchors would instead face a tension between external adjustment and a desire to maintain a stable nominal exchange rate against the euro, as a precursor to eventual euro adoption. A key policy issue in these countries is ensuring that the economies are flexible enough to cope with potentially large shift in international relative prices and external demand.

\footnotetext{
29 See Lane and Milesi-Ferretti (2007a) for a discussion of capital flows to CEE countries.

${ }^{30}$ In addition to the direct valuation effects from holding U.S. assets, European wealth may be affected indirectly via the transmission of financial shocks in the U.S. to asset prices in Europe and other regions. At one level, European asset prices may be negatively affected through the decline in wealth of investors taking losses in the US. Coeurdacier (2005) provides a recent theoretical model of this mechanism.

${ }^{31}$ The vulnerability of high current account deficit countries to a decline in global liquidity is well exemplified by the sharp decline in the Icelandic krona during the first half of 2006.
} 


\section{Conclusions}

This paper has attempted to assess the potential impact on Europe of an unwinding of global imbalances. We have emphasized that the growth in trade and financial linkages between Europe and the rest of the world means that the spillover impact on Europe of a contraction in the U.S. deficit and Asian surpluses is now larger than twenty years ago. That said, we have also shown that the scale of global integration in trade and finance remains limited, and the exposure of Europe to external shocks should not be overstated.

In terms of overall adjustment, the model simulations show possible paths for current accounts, real exchange rates, and growth under alternative adjustment scenarios. In particular, they highlight how a reduction in the U.S. trade deficit is likely to be associated with substantial real dollar depreciation, but_-if exchange rates in Asia are allowed to adjust—need not imply large real exchange rate changes for the euro area.

The scenarios also suggest that "structural reforms" in the euro area-broadly interpreted to encompass measures that increase competition in goods and labor markets and stimulate productivity growth — can help the adjustment process from a global perspective by modestly helping U.S. current account adjustment, but especially by helping sustain world growth. Of course, the most important dimension of these policies is their domestic impact on European economic performance. However, with increasing levels of global economic integration, even the determination of domestically-orientated policies must take into account international factors. Indeed, a major motivation for structural reforms is to boost the flexibility of European economies so as to improve their capacity to cope with globalization and swings in the external environment.

A particular contribution of our paper has been to quantify the importance of the valuation channel in these alternative adjustment scenarios. In particular, we have shown that the exposure of Europe to the dollar, while non-negligible, is much smaller than the exposure of emerging Asia and Japan. To the extent that a real effective depreciation of the dollar occurs primarily vis-à-vis the largest creditor countries and regions_emerging Asia, Japan, and oil exporters - the consequences for Europe in general, and the euro area in particular, would not be large.

Clearly, the risks for Europe are much more significant if creditor country currencies, many of which closely track the U.S. dollar, fail to adjust, so that at least in the short term a weakening of the dollar would imply a substantial real effective appreciation for Europe and the euro area. In turn, this could have strong negative repercussions on activity, underscoring the importance of policy measures that help sustain output and demand.

Looking forward, a shift in international portfolio preferences may well be associated with an increase in the role of the euro as a reserve currency (see, for example, Chinn and Frankel, 2007). While we have not addressed this issue in the paper, one could envisage scenarios 
where net exports are negatively affected by the appreciation of the euro, but economic activity benefits from a decline in required returns on euro area assets.

Finally, we have probed possible differences across European economies in their vulnerability to a shift in global imbalances. While there is substantial variation in the extent of trade and financial linkages between individual European countries and the United States and Asia, the scale of such linkages is limited even for the most exposed countries (with the possible exception of Ireland). If this shift were to be accompanied by a less benign international financial environment, characterized by higher spreads on debtor countries and less bountiful capital flows, some countries in Central and Eastern Europe may be forced to undergo a sharp adjustment in their external accounts. 


\section{Appendix 1. Decomposition of Changes in Net Foreign Assets}

In earlier work, we have developed an accounting framework that is helpful in thinking about the dynamics of external positions (Lane and Milesi-Ferretti 2005a, 2005b). We provide a brief presentation of this framework in this appendix.

The change in the net foreign asset position $B$ can be written as follows:

$$
B_{t}-B_{t-1}=C A_{t}+K G_{t}+E_{t}
$$

where $B_{t}$ is the net foreign asset position, $C A_{t}$ is the current account balance, $K G_{t}$ is the capital gain or loss on net foreign assets (equal to the change in stocks minus the underlying flows) and the term $E_{t}$ includes factors such as capital account transfers (the so-called capital account balance) and errors and omissions that drive a wedge between a country's current account and net inflows of capital. In turn, the current account $C A_{t}$ equals the sum of the balance on goods, services, and current transfers $B G S T_{t}$ and the investment income balance $i_{t}^{A} A_{t-1}-i_{t}^{L} L_{t-1}$, where $A$ and $L$ are external assets and liabilities, respectively, and $i_{t}^{A}, i_{t}^{L}$ are the nominal yields on these assets and liabilities. ${ }^{32}$

Indicating ratios to GDP with lower-case letters, we can express (1) as follows:

$$
b_{t}-b_{t-1} \equiv b g s t_{t}+\frac{i_{t}^{A} A_{t-1}-i_{t}^{L} L_{t-1}}{Y_{t}}+\frac{K G_{t}}{Y_{t}}-\frac{g_{t}+\pi_{t}}{\left(1+g_{t}\right)\left(1+\pi_{t}\right)} b_{t-1}+\varepsilon_{t}
$$

where $g_{t}$ is the growth rate of real GDP, $\pi_{t}$ is the inflation rate, and the term $\varepsilon$ includes the ratio of capital transfers and errors and omissions to GDP. The second and third term on the right-hand-side of equation (2) captures the effect of nominal returns on external assets and liabilities on the evolution of the external position. To see this more clearly, define $\mathrm{kg}_{t}^{A}\left(\mathrm{~kg}_{t}^{L}\right)$ as the ratio of the capital gain on external assets (liabilities), measured in domestic currency, to the outstanding stock of external assets (liabilities) at the beginning of the period, so that $k g_{t}^{A} A_{t-1}-k g_{t}^{L} L_{t-1}=K G_{t}$. Then the real rate of return on foreign assets, measured in domestic currency, will equal $r_{t}^{A}=\frac{1+i_{t}^{A}+k g_{t}^{A}}{1+\pi_{t}}-1$, and an analogous definition will hold for

\footnotetext{
${ }^{32}$ We incorporate international labor income in the term BGST.
} 
the rate of return on foreign liabilities $r_{t}^{L}$. Using these definitions, we can re-write (2) as follows: ${ }^{33}$

$$
b_{t}-b_{t-1} \equiv b g s t_{t}+\frac{r_{t}^{L}-g_{t}}{1+g_{t}} b_{t-1}+\frac{r_{t}^{A}-r_{t}^{L}}{1+g_{t}} a_{t-1}+\varepsilon_{t}
$$

This framework delivers several important insights. First, the trade balance is only one factor in determining the aggregate evolution of the net foreign asset position: the "intrinsic dynamics" of net foreign assets depend on the difference between the rate of return on liabilities and the growth rate, captured by the second term on the RHS of (3), which is familiar from the standard debt accumulation equation. The importance of this effect depends on a country's net foreign asset position-an increase in the rate of return improves the net foreign asset position of a creditor but is adverse for a debtor.

Second, when rates of return on external assets and liabilities differ, the gross scale of external assets and liabilities matters in addition to the net position, as shown by the last term on the RHS of equation (3). Differences in rates of return between external assets and liabilities can arise for various reasons: ${ }^{34}$

- In larger advanced economies, assets tend to be denominated in foreign currency and liabilities mostly in domestic currency. Consequently, an unexpected exchange rate depreciation (not reflected in ex-ante interest differentials) will increase the domesticcurrency rate of return on external assets and hence improve the net foreign asset position. More generally, differences in the portfolio composition of external assets and liabilities (for example, differences in the debt-equity mix) can imply differences in rates of return.

- In contrast, for emerging markets that are net debtors and whose external liabilities are primarily denominated in foreign currency, a real exchange rate depreciation raises the domestic-currency burden of foreign liabilities. In recent years, however, a trend towards a larger share of external liabilities denominated in domestic currency is at play in emerging markets as well, driven in particular by the increased importance of foreign FDI and portfolio equity investment.

- Differential changes in asset prices (for example, in stock prices) across countries will tend to drive a wedge between returns on external assets and liabilities.

\footnotetext{
${ }^{33}$ The same equation can be written using real rates of return in dollars, rather than domestic currency, using the equivalence $1+r_{t}^{\$}=\left(1+r_{t}\right)\left(1+s_{t}\right)$ where $s_{t}$ is the rate of real domestic-currency appreciation vis-à-vis the US dollar.

${ }^{34}$ See also the extended discussion in Lane and Milesi-Ferretti (2005a).
} 


\section{Appendix 2. Estimating the Currency Composition of Net Foreign Assets}

This Appendix summarizes the methodology used to estimate the currency composition of net foreign assets for the euro area, as well as for China, Japan, and the United States.

\section{A. The Euro Area}

We rely on a variety of sources, described more in detail below, and we focus in particular on holdings denominated in U.S. dollars and in euros.

\section{External assets}

For foreign direct investment abroad and portfolio equity investment assets, we assume that investment in each country is denominated in the currency of that country. In particular, all euro area holdings in the United States and half of FDI in offshore centers are assumed to be denominated in dollars. Data on the geographical breakdown of the euro area's International Investment Position at end-2004 comes from the August 2006 ECB Bulletin. The share of investment in dollars is assumed to be unchanged in 2005.

For portfolio debt assets, ECB (2005) reports the currency breakdown between euro and other currencies at end-2004. To estimate the weight of the dollar in other currencies, we use statistics on the currency composition of portfolio debt holdings by euro area Monetary and Financial Institutions (MFIs), reported by the ECB, and assume that the dollar share in noneuro currencies is the same for non-MFI portfolio debt holdings. In light of the 6 percentage point decline in the share of euro-denominated portfolio debt holdings by MFIs between end2004 and end-2005, we assume a 5 percent decline in the share of total euro-denominated holdings in 2005 relative to 2004.

For other investment assets, we assume that all euro area investment in the United States and half of the investment in offshore centers is denominated in dollars, with the remainder assumed to be denominated in euros. We again rely on the geographical breakdown of the euro area International Investment Position at end-2004 from the August 2006 ECB Bulletin.

For foreign exchange reserves, we assume a 90 percent weight for the U.S. dollar.

\section{External liabilities}

For foreign direct investment and portfolio equity investment in the euro area, we assume that all liabilities are denominated in euros.

For portfolio debt liabilities, we use the currency breakdown between euro and other currencies at end-2004 reported in ECB (2005). We assume that the dollar share in non-euro debt liabilities is 60 percent, in line with BIS data on the currency composition of international banking liabilities in the euro area. 
For other investment liabilities, we assume that the share denominated in dollars is 25 percent, with the remainder denominated in euros. This assumption ensures that the net dollar position in the "other investment" category is broadly balanced.

\section{B. China}

We have virtually no direct information on the currency composition of China's external position, and hence our assumptions are subject to significant uncertainty.

\section{External assets}

For foreign direct investment abroad and portfolio equity investment assets, we assume for simplicity that Chinese holdings in the United States are zero. The United States currently reports 2005 FDI holdings by China at historical cost of around US\$1/2 billion.

For portfolio debt assets and other investment assets, we assume that all Chinese overseas holdings are denominated in U.S. dollars.

For foreign exchange reserves, we assume a 75 percent weight for the U.S. dollar and a 25 percent weight for the euro.

\section{External liabilities}

For foreign direct investment and portfolio equity investment in China, we assume that all liabilities are denominated in renmimbi.

For portfolio debt and other investment, we assume that all liabilities are denominated in U.S. dollars.

\section{Japan}

We rely primarily on data from the Bank of Japan.

\section{External assets}

For foreign direct investment abroad and portfolio equity investment assets, we assume investment in each country is denominated in the currency of that country. In particular, all Japanese investment in the United States and half of Japan's FDI in offshore centers is assumed to be denominated in dollars. Data on the geographical breakdown of Japan's portfolio equity and FDI assets comes from the CPIS and the Bank of Japan, respectively.

For portfolio debt assets, we use Bank of Japan's data on the currency composition of portfolio debt holdings by Japanese residents (available at http://www.boj.or.jp/en/type/stat/boj_stat/bop/pip/pip2005.zip) 
For other investment, we assume that the net position (assets minus liabilities) — which is negative at 3-4 percent of GDP-is denominated in U.S. dollars.

For foreign exchange reserves, we assume a 75 percent weight for the U.S. dollar and a 25 percent weight for the euro. ${ }^{35}$

\section{External liabilities}

For foreign direct investment and portfolio equity investment in the Japan, we assume that all liabilities are denominated in yen.

For portfolio debt liabilities, we assume that a 90 percent share is denominated in yen and a 10 percent share in U.S. dollars. Data from the U.S. Treasury Report on U.S. Portfolio Holdings of Foreign Securities indicates that 95 percent of U.S. portfolio debt claims in Japan are yen-denominated.

For other investment liabilities, see the discussion of the "other investment" category above.

\section{United States}

Our primary sources are Nguyen (2006), who reports details on the U.S. International Investment Position, and Tille (2005), who describes available sources for determining the currency composition of the U.S. external portfolio. We focus in particular on the determination of the net dollar position and the net foreign-currency position.

\section{External assets}

For foreign direct investment abroad, we rely on the geographical data at historical cost published by the Bureau of Economic Analysis (2006), and approximate the market value by multiplying historical cost holdings by the ratio of aggregate market value to historical cost value. We assume that FDI in each country is denominated in the currency of that country.

For portfolio equity assets, we rely on the U.S. Treasury report on U.S. Portfolio Holdings of Foreign Securities at end-2004 (http://www.treas.gov/tic/shc2004r.pdf), which reports the geographical distribution of U.S. portfolio holdings, assuming that portfolio equity holdings in each country are denominated in the currency of that country. We update the data to 2005 by assuming that the individual country shares of total portfolio equity holdings remain unchanged.

For portfolio debt holdings we rely on the same report, which also contains information on the currency composition of these holdings (Tables 21 and 22).

\footnotetext{
${ }^{35}$ Truman and Wong (2006) argue that the weight of the dollar is likely to exceed 80 percent.
} 
For other investment assets, we use the reported currency breakdown between dollar and foreign currencies for bank claims (Nguyen (2006), Table D) and assume that the breakdown for nonbank claims has the same currency composition. Bank claims account for around $3 / 4$ of total other investment assets.

For foreign exchange reserves, we use data from the U.S. Treasury (available at the link http://www.treas.gov/press/releases/20061119281827487.htm.

\section{External liabilities}

For foreign direct investment and portfolio equity investment in the United States, we assume that all liabilities are denominated in U.S. dollars.

For portfolio debt liabilities, we use data published in the Report on Foreign Portfolio Holdings of U.S. Securities as of June 30, 2005 (http://www.treas.gov/tic/shl2005r.pdf). which provides the currency composition of long-term debt securities, and apply the same currency share to short-term debt securities. The currency shares are assumed to have remained constant between June and December 2005.

For other investment liabilities, we use the reported currency breakdown between dollar and foreign currencies for claims reported by banks (Nguyen (2006), Table I) and assume that the breakdown for the remaining claims has the same currency composition. Claims on banks account for around 70 percent of total other investment liabilities. 


\section{References}

Bayoumi, Tamim, Jaewoo Lee, and Sarma Jayanthi, 2005, “New Rates for New Weights,” IMF Working Paper 05/99 (Washington: International Monetary Fund).

Blanchard, Olivier, 2006, “Adjustment within the Euro: The Difficult Case of Portugal,” mimeo, MIT.

— Account, and The Dollar,” Brookings Papers on Economic Activity No. 1, pp. 1-65.

Campbell, John, Karine Serfaty-de Medeiros, and Luis Viceira, 2006, “Global Currency Hedging,” mimeo, Harvard University.

Cavallo, Michele and Cédric Tille, 2006, “Could Capital Gains Smooth a Current Account Rebalancing?” Federal Reserve Bank of New York, Staff Report No. 237.

Chinn, Menzie and Jeffrey Frankel, 2007, "Will the Euro Eventually Surpass the Dollar as Leading International Reserve Currency?” forthcoming in G7 Current Account Imbalances: Sustainability and Adjustment, edited by Richard Clarida (Chicago: Chicago University Press for NBER).

Coeurdacier, Nicolas, 2006, "Do Trade Costs in Goods Market Lead to Home Bias in Equities? Mimeo, Paris-Jourdan Sciences Economiques.

Devereux, Michael B. and Alan Sutherland, 2006, "Country Portfolios in Open Economy Macro Models,” mimeo, University of British Columbia and St Andrews University.

— and Charles Engel, 2006, "Expectations and Exchange Rate Policy," mimeo, University of British Columbia and University of Wisconsin.

Eichengreen, Barry and Yung Chul Park, 2006, "Global Imbalances: Implications for Emerging Asia and Latin America,” mimeo, UC-Berkeley.

Elliott, John and Erica Wong Min, 2004, “The External Balance Sheet of the United Kingdom: Recent Developments” (Bank of England Quarterly Bulletin: Winter).

Engel, Charles and Akito Matsumoto, 2006, "Portfolio Choice in a Monetary Open-Economy DSGE Model,” NBER Working Paper No. 12214 (May).

and John Rogers, 2006, “The U.S. Current Account Deficit and the Expected Share of World Output,” Journal of Monetary Economics, No. 53, pp. 1063-93. 
Erceg, Christopher, Luca Guerrieri, and Christopher Gust, 2005, "SIGMA: A New Open Economy Model for Policy Analysis,” Federal Reserve Board, International Finance, Discussion Paper No. 835.

European Central Bank, 2005, Review of the International Role of the Euro, Frankfurt, Germany: European Central Bank (http://www.ecb.int/pub/pdf/other/eurointernational-role200512en.pdf).

European Economic Advisory Group, 2006, Report on the European Economy 2006, CESifo.

Faruqee, Hamid, 2004, "Global Rebalancing of Current Accounts: A Euro-Area Perspective,” in Euro Area Policies: Selected Issues, IMF Country Report 04/235 (August).

— Global Imbalances and Spur Economic Activity? A Scenario Analysis,” NBER Working Paper No. 12704.

—_ Douglas Laxton, Dirk Muir, and Paolo Pesenti, 2005, "Smooth Landing or Crash? Model-Based Scenarios of Global Current Account Rebalancing," forthcoming in G7 Current Account Imbalances: Sustainability and Adjustment, edited by Richard Clarida, (Chicago: Chicago University) Press for NBER.

Ghironi, Fabio, Jaewoo Lee, and, Alessandro Rebucci, 2007, “The Valuation Channel of External Adjustment,” NBER Working Paper No. 12937 (February).

Gourinchas, Pierre-Olivier and Hélène Rey, 2005a, "International Financial Adjustment," NBER Working Paper No. 11155 (August). and Hélène Rey, 2007, "From World Banker to World Venture Capitalist: US External Adjustment and the Exorbitant Privilege," forthcoming in G7 Current Account Imbalances: Sustainability and Adjustment, edited by Richard Clarida, Chicago: Chicago University Press for NBER.

Harald, Hau and Helene Rey, 2006, "Exchange Rates, Equity Prices and Capital Flows," Review of Financial Studies, Vol. 19 (1), pp. 273-317.

Honohan, Patrick and Philip R. Lane, 1999, "Pegging to the Dollar and the Euro," International Finance, Vol. 2 No. 3, pp. 379-410.

— , 2003, “Divergent Inflation Rates under EMU,” Economic Policy, Vol. 18, No. 37 (October), pp. 359-94. 
Hunt, Benjamin and Alessandro Rebucci, 2005, "The U.S. Dollar and the Trade Deficit: What Accounts for the Late 1990s?" International Finance, Vol. 8, No. 3, pp. 399-434.

International Monetary Fund, 2005a, “Globalization and External Imbalances,” World Economic Outlook, Chapter III, April (Washington, DC: International Monetary Fund).

— I.2, September (Washington, DC: International Monetary Fund).

— , 2006, World Economic Outlook, Box 1.3, September (Washington, DC: International Monetary Fund).

Krugman, Paul, 2007, “Will There Be a Dollar Crisis?” Economic Policy, forthcoming.

Kumhof, Michael, Douglas Laxton, and Dirk Muir, 2005, “The Consequences of U.S. Fiscal Consolidation for the Current Account," in United States: Selected Issues, IMF Country Report No. 05/258 (Washington DC: International Monetary Fund).

Lane, Philip R., and Gian Maria Milesi-Ferretti, 2001, “The External Wealth of Nations: Measures of Foreign Assets and Liabilities for Industrial and Developing Countries,” Journal of International Economics, Vol. 55, pp. 263-94.

— pp. 82-113 (Washington: International Monetary Fund).

— 05/03 (Washington: International Monetary Fund).

—, 2006, “The External Wealth of Nations Mark II,” IMF Working Paper No. 06/169, March (forthcoming, Journal of International Economics).

— 2007a, “Capital Flows to Central and Eastern Europe,” Emerging Markets Review 8 No. 2 (May), pp. 106-23.

—, 2007b, “A Global Perspective on External Positions,” forthcoming in G7 Current Account Imbalances: Sustainability and Adjustment, edited by Richard Clarida (Chicago: Chicago University Press for NBER.)

Martin, Philippe and Helene Rey, 2000, “Financial Integration and Asset Returns,” European Economic Review, No. 44, pp. 1327-50. and Helene Rey, 2004, "Financial Super-Markets: Size Matters for Asset Trade,” Journal of International Economics, Vo. 64, No. 2 (December), pp. 335-61. 
Nguyen, Elena L. 2006, “The International Investment Position of the United States at Yearend 2005,” Survey of Current Business (July), pp. 9-19.

Obstfeld, Maurice and Kenneth Rogoff, 2000, "Perspectives on OECD Capital Market Integration: Implications for U.S. Current Account Adjustment,” in Global Economic Integration: Opportunities and Challenges, Federal Reserve Bank of Kansas City, pp. 169-208.

and Kenneth Rogoff, 2005, "Global Current Account Imbalances and Exchange Rate Adjustments,” Brookings Papers on Economic Activity, Vol. 1, pp. 67-146.

and Kenneth Rogoff, 2007, “The Unsustainable US Current Account Position Revisited,” forthcoming in G7 Current Account Imbalances: Sustainability and Adjustment, edited by Richard Clarida (Chicago: Chicago University Press for NBER).

Thomas, Charles P., Francis E. Warnock, and Jon Wongswan, 2004, “The Performance of International Portfolios,” International Finance Discussion Paper No. 817, Board of Governors of the Federal Reserve System.

Tille, Cédric, 2003, “The Impact of Exchange Rate Movements on U.S. Foreign Debt,” Current Issues in Economics and Finance No. 9, Vol. 1 (Federal Reserve Bank of New York: New York).

— 2005, "Financial Integration and the Wealth Effect of Exchange Rate Fluctuations," (Federal Reserve Bank of New York: New York) Staff Report No. 226.

Truman, Edwin M. and Anna Wong, 2006, “The Case for An International Reserve Diversification Standard,” Institute for International Economics, Working Paper No. 06/2 (May).

Warnock, Frank, 2006, “How Might a Disorderly Resolution of Global Imbalances Affect Global Wealth?” IMF Working Paper No. 06/170 (Washington: International Monetary Fund). 
Table 1. Direction of Trade in Goods, 1984 and 2004

\begin{tabular}{|c|c|c|c|c|c|c|}
\hline \multicolumn{7}{|c|}{1984} \\
\hline Trading Partner $\rightarrow$ & Europe 1/ & $\begin{array}{r}\text { United } \\
\text { States }\end{array}$ & Japan & $\begin{array}{r}\text { Emerging } \\
\text { Asia }\end{array}$ & Other & Total \\
\hline \multicolumn{7}{|l|}{ Country/Region $\downarrow$} \\
\hline Euro Area & 8 & 4 & 1.1 & 1.6 & 12.4 & 26.9 \\
\hline United States & 3.3 & & 2.1 & 2.2 & 6.6 & 14.2 \\
\hline Japan & 2.9 & 6.9 & & 6.1 & 8.3 & 24.2 \\
\hline Emerging Asia & 5.7 & 9.3 & 8.5 & & 8.6 & 32.5 \\
\hline \multicolumn{7}{|c|}{2004} \\
\hline Trading Partner $\rightarrow$ & Europe 1/ & $\begin{array}{r}\text { United } \\
\text { States }\end{array}$ & Japan & $\begin{array}{r}\text { Emerging } \\
\text { Asia }\end{array}$ & Other & Total \\
\hline \multicolumn{7}{|l|}{ Country/Region $\downarrow$} \\
\hline Euro Area & 8.6 & 3.9 & 1.2 & 4.2 & 11.8 & 29.8 \\
\hline United States & 4.1 & & 1.6 & 4.8 & 9.6 & 20 \\
\hline Japan & 3.2 & 4.1 & & 10 & 4.5 & 21.8 \\
\hline Emerging Asia & 12 & 12 & 11.4 & & 14.8 & 51.1 \\
\hline \multicolumn{7}{|c|}{$\begin{array}{l}\text { 1/ Includes Denmark, Norway, Sweden, Switzerland, and the United Kingdom as euro area partner } \\
\text { countries, and these } 5 \text { countries plus the euro area as trading partners for other countries and regions. }\end{array}$} \\
\hline \multicolumn{7}{|c|}{$\begin{array}{l}\text { Note: Bilateral exports and imports as a ratio of country/region’s domestic GDP. For the euro area, the } \\
\text { Europe category excludes intra-euro area trade. Sum of regions does not add to total, due to unallocated } \\
\text { trade. Source: authors' calculations based on IMF Direction of Trade Statistics. Emerging Asia includes } \\
\text { China, Hong Kong S.A.R., India, Indonesia, Korea, Malaysia, Philippines, Singapore, Taiwan province of } \\
\text { China, and Thailand. }\end{array}$} \\
\hline
\end{tabular}


Table 2. Evolution of Net Foreign Assets, 2002-2005: Underlying Factors 2002-2005

\begin{tabular}{|c|c|c|c|c|c|c|c|}
\hline Factor $\rightarrow$ & $\begin{array}{r}\text { NFA at } \\
\text { end-2001 }\end{array}$ & $\begin{array}{l}\text { Change } \\
\text { in NFA } \\
\text { 2001-05 }\end{array}$ & $\begin{array}{r}\text { Cumul. } \\
\text { trade } \\
\text { balance }\end{array}$ & $\begin{array}{r}\text { Cumul } \\
\text { investm. } \\
\text { income }\end{array}$ & $\begin{array}{r}\text { Valuation } \\
\text { changes }\end{array}$ & $\begin{array}{l}\text { Effects of } \\
\text { growth }\end{array}$ & $\begin{array}{r}\text { Other } \\
\text { factors } 1 /\end{array}$ \\
\hline Term in eq (2) $\rightarrow$ & $b_{01}$ & $b_{05}-b_{01}$ & $\sum_{t=2002}^{2005} b g s t_{t}$ & $\sum_{t=2002}^{2000}\left(\frac{i_{t}^{A} A_{t-1}-i_{t}^{L} L_{t-1}}{Y_{t}}\right)$ & $\sum_{t=2002}^{2005} \frac{K G_{t}}{Y_{t}}$ & 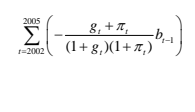 & $\sum_{t=2002}^{2005} \varepsilon_{t}$ \\
\hline Euro Area & -7.2 & -7.2 & 3.3 & -2.0 & -9.2 & 2.7 & -1.9 \\
\hline Japan & 32.5 & 0.8 & 5.7 & 7.1 & -7.4 & -2.9 & -1.7 \\
\hline United States & -23.8 & 2.3 & -20.6 & 0.9 & 17.2 & 4.5 & 0.4 \\
\hline
\end{tabular}

1/ Cumulative capital account transfers and errors and omissions.

Note: the decomposition of the dynamics of net foreign assets is according to equation (2) in Appendix 1: $b_{05}-b_{01} \equiv \sum_{t=2002}^{2005}\left(b g s t_{t}+\frac{i_{t}^{A} A_{t-1}-i_{t}^{L} L_{t-1}}{Y_{t}}+\frac{K G_{t}}{Y_{t}}-\frac{g_{t}+\pi_{t}}{\left(1+g_{t}\right)\left(1+\pi_{t}\right)} b_{t-1}+\varepsilon_{t}\right)$

Source: Authors' calculations based on IMF, Balance of Payments Statistics, national data, and Lane and Milesi-Ferretti (2006). 
Table 3. Capital Gains on External Portfolios in the Euro Area and the United States, 2002-2005

\begin{tabular}{|c|c|c|c|c|c|c|c|}
\hline \multicolumn{5}{|c|}{ Euro Area } & \multicolumn{3}{|c|}{ United States } \\
\hline & \multicolumn{3}{|c|}{ Assets } & & \multicolumn{3}{|c|}{ Assets } \\
\hline & $\begin{array}{l}\text { Portf. } \\
\text { debt }\end{array}$ & $\begin{array}{l}\text { Portf. } \\
\text { equity }\end{array}$ & FDI & $\begin{array}{r}\text { Exchange } \\
\text { rate } € / \$ \text { (pct } \\
\text { change) }\end{array}$ & $\begin{array}{r}\text { Portf. } \\
\text { debt }\end{array}$ & $\begin{array}{l}\text { Portf. } \\
\text { equity }\end{array}$ & FDI \\
\hline 2002 & -7.5 & -26.5 & -11.5 & -16 & 20.9 & -15.8 & -19.3 \\
\hline 2003 & 0.1 & 18.8 & 1.1 & -17 & 18.0 & 43.0 & 28.0 \\
\hline 2004 & 1.3 & 8.9 & -1.4 & -7.3 & 11.4 & 19.1 & 11.2 \\
\hline 2005 & 8.3 & 21.3 & 3.5 & 15.5 & -2.4 & 15.2 & 6.5 \\
\hline \multicolumn{4}{|c|}{ Liabilities } & & \multicolumn{3}{|c|}{ Liabilities } \\
\hline & $\begin{array}{r}\text { Portf. } \\
\text { debt }\end{array}$ & $\begin{array}{l}\text { Portf. } \\
\text { equity }\end{array}$ & FDI & & $\begin{array}{r}\text { Portf. } \\
\text { debt }\end{array}$ & $\begin{array}{l}\text { Portf. } \\
\text { equity }\end{array}$ & FDI \\
\hline 2002 & 3.9 & -21.3 & -0.1 & & 1.4 & -18.3 & -24.2 \\
\hline 2003 & -1.9 & 6.0 & 8.7 & & -1.6 & 35.3 & 18.1 \\
\hline 2004 & 4.5 & 7.3 & 2.5 & & -0.6 & 12.7 & 5.8 \\
\hline 2005 & 6.0 & 20.7 & 1.1 & & -7.6 & 4.7 & 1.3 \\
\hline
\end{tabular}

Note: Rate of capital gains in euro on foreign assets and liabilities of the euro area; Rates of capital gains in dollars on foreign assets and liabilities of the United States. Source: authors' calculations based on Lane and Milesi-Ferretti (2006). 
Table 4. Currency Composition of Net External Position, 2005 (percent of GDP)

\begin{tabular}{lrrrr}
\hline & $\begin{array}{r}\text { Net external } \\
\text { position }\end{array}$ & $\begin{array}{r}\text { Net domestic } \\
\text { currency position }\end{array}$ & $\begin{array}{r}\text { Net U.S. dollar } \\
\text { position }\end{array}$ & $\begin{array}{r}\text { Net other } \\
\text { currencies } \\
\text { position }\end{array}$ \\
China & 12.5 & -28.3 & 29.2 & 11.6 \\
Euro Area & -15.0 & -65.5 & 16.8 & 34.5 \\
Japan & 35.9 & -26.9 & 38.5 & 21.9 \\
United States & -21.5 & $(-74.8)$ & -74.8 & 53.4 \\
\hline
\end{tabular}

Source: authors’ calculations (see Appendix 2). 
Table 5. Net Foreign Assets and Capital Gains, Adjustment Scenarios: Effects of Exchange Rates and Asset Prices

\begin{tabular}{|c|c|c|c|c|}
\hline & China & Euro Area & Japan & United States \\
\hline Net foreign assets, 2005 (pct of GDP) & 12.5 & -15.0 & 35.9 & -21.5 \\
\hline Financial openness, 2005 (pct of GDP) 1/ & 95.9 & 269.7 & 163.8 & 196.8 \\
\hline \multicolumn{5}{|l|}{ Baseline } \\
\hline Net foreign assets, 2008 (pct of GDP) & 24.0 & -16.3 & 34.3 & -33.5 \\
\hline PV of capital gains/losses by 2008 (pct of 2005 GDP) & -4.0 & -3.5 & -8.6 & 2.1 \\
\hline of which: exchange rate-related capital gains & -3.0 & -4.3 & -8.1 & 0.4 \\
\hline Net foreign assets, 2015 (pct of GDP) & 26.1 & -14.4 & 38.0 & -43.4 \\
\hline PV of capital gains/losses by 2015 (pct of 2005 GDP) & -18.4 & -5.5 & -16.3 & 8.4 \\
\hline of which: exchange rate-related capital gains & -12.4 & -7.6 & -16.0 & 3.9 \\
\hline \multicolumn{5}{|l|}{ Policies scenario } \\
\hline Net foreign assets, 2008 (pct of GDP) & 21.9 & -15.8 & 33.9 & -30.9 \\
\hline PV of capital gains/losses by 2008 (pct of 2005 GDP) & -5.2 & -3.6 & -9.3 & 3.7 \\
\hline of which: exchange rate-related capital gains & -4.2 & -3.9 & -8.4 & 1.8 \\
\hline Net foreign assets, 2015 (pct of GDP) & 15.3 & -14.4 & 32.4 & -24.5 \\
\hline PV of capital gains/losses by 2015 (pct of 2005 GDP) & -17.1 & -6.7 & -17.5 & 10.0 \\
\hline of which: exchange rate-related capital gains & -10.7 & -6.5 & -15.0 & 4.0 \\
\hline \multicolumn{5}{|l|}{ Disruptive scenario } \\
\hline Net foreign assets, 2008 (pct of GDP) & 15.5 & -18.0 & 23.6 & -24.7 \\
\hline PV of capital gains/losses by 2008 (pct of 2005 GDP) & -16.0 & -4.1 & -17.2 & 6.9 \\
\hline of which: exchange rate-related capital gains & -15.1 & -5.0 & -16.1 & 5.1 \\
\hline
\end{tabular}

1 / Sum of external assets and liabilities (in percent of GDP).

Note: exchange-rate-related capital gains are calculated by excluding the effects of economic growth on the value of portfolio equity assets and liabilities 
Table 6a. European Countries: Bilateral Trade Patterns, 2004

\begin{tabular}{lrrrrrr}
\hline & Europe & $\begin{array}{r}\text { United } \\
\text { States }\end{array}$ & Japan & $\begin{array}{r}\text { Emerging } \\
\text { Asia }\end{array}$ & $\begin{array}{r}\text { Rest of the } \\
\text { World }\end{array}$ & Total \\
Austria & 69.4 & 3.2 & 1.0 & 2.8 & 5.8 & 82.2 \\
Belgium & 128.0 & 10.1 & 3.3 & 8.1 & 19.2 & 168.7 \\
Finland & 40.0 & 3.0 & 1.3 & 4.5 & 11.8 & 60.7 \\
France & 32.1 & 2.6 & 0.7 & 2.4 & 7.1 & 45.1 \\
Germany & 40.7 & 4.8 & 1.5 & 5.2 & 7.2 & 59.4 \\
Greece & 21.0 & 1.5 & 0.8 & 2.7 & 7.1 & 33.1 \\
Ireland & 60.7 & 15.9 & 2.6 & 5.8 & 6.1 & 91.1 \\
Italy & 27.0 & 2.4 & 0.7 & 1.9 & 10.2 & 42.2 \\
Netherlands & 81.9 & 7.0 & 2.5 & 11.5 & 14.2 & 117.2 \\
Portugal & 43.3 & 2.1 & 0.6 & 1.5 & 6.7 & 54.2 \\
Spain & 32.1 & 1.5 & 0.7 & 2.3 & 7.8 & 44.3 \\
Denmark & 45.5 & 2.7 & 1.2 & 3.9 & 5.6 & 58.9 \\
Norway & 39.8 & 3.7 & 1.1 & 2.7 & 4.9 & 52.2 \\
Sweden & 48.1 & 4.8 & 1.3 & 3.8 & 6.5 & 64.4 \\
Switzerland & 48.3 & 5.3 & 2.0 & 5.0 & 6.3 & 66.9 \\
United Kingdom & 21.5 & 4.4 & 1.0 & 4.0 & 6.5 & 37.4 \\
Central and & 59.1 & 2.3 & 1.2 & 4.3 & 11.6 & 78.4 \\
Eastern Europe & & & & & & \\
\hline
\end{tabular}

Note: (Exports+Imports)/GDP. Source: IMF, Direction of Trade Statistics. 
Table 6b. Trade Weights in Multilateral Real Exchange Rates

\begin{tabular}{lrrrr}
\hline & Europe & $\begin{array}{r}\text { United } \\
\text { States }\end{array}$ & Asia & $\begin{array}{r}\text { Rest of } \\
\text { the world }\end{array}$ \\
Austria & 0.78 & 0.08 & 0.07 & 0.07 \\
Belgium-Luxembourg & 0.78 & 0.09 & 0.08 & 0.06 \\
Finland & 0.64 & 0.09 & 0.12 & 0.14 \\
France & 0.72 & 0.1 & 0.1 & 0.08 \\
Germany & 0.68 & 0.11 & 0.11 & 0.09 \\
Greece & 0.72 & 0.08 & 0.07 & 0.14 \\
Ireland & 0.64 & 0.21 & 0.1 & 0.05 \\
Italy & 0.69 & 0.11 & 0.1 & 0.1 \\
Netherlands & 0.81 & 0.07 & 0.07 & 0.05 \\
Portugal & 0.82 & 0.08 & 0.05 & 0.04 \\
Spain & 0.78 & 0.07 & 0.07 & 0.08 \\
Denmark & 0.76 & 0.08 & 0.1 & 0.06 \\
Sweden & 0.69 & 0.13 & 0.1 & 0.08 \\
United Kingdom & 0.61 & 0.18 & 0.12 & 0.09 \\
CEEC & 0.8 & 0.05 & 0.05 & 0.1 \\
Japan & 0.28 & 0.29 & 0.32 & 0.11 \\
United States & 0.32 & 0 & 0.26 & 0.42 \\
\hline
\end{tabular}

Note: “Double export” weights from European Commission's basket of 41 major trading partners for 2004. 
Table 7. Net Dollar Exposures

(in percent of GDP), 2004

\begin{tabular}{lrrrrr}
\hline & FDI & Portfolio & Portfolio & Bank & $\begin{array}{r}\text { FDI } \\
\text { Assets }\end{array}$ \\
Equity & Debt & & Liabilities \\
Austria & 1.6 & 5.6 & 3.1 & -3.0 & 2.2 \\
Belgium & 5.0 & 3.9 & 17.1 & -2.2 & 7.9 \\
Finland & 4.1 & 3.7 & 4.7 & -3.0 & 0.8 \\
France & 8.9 & 5.7 & 0.1 & -4.4 & 3.9 \\
Germany & 7.7 & 2.5 & 4.4 & 4.3 & 4.2 \\
Greece & 0.6 & 0.9 & 0.4 & & 0.8 \\
Ireland & 10.4 & & & -9.6 & 68.8 \\
Italy & 1.6 & 4.1 & 0.2 & -2.4 & 1.4 \\
Luxembourg & 1.1 & & & 97.2 & 27.0 \\
Netherlands & 22.6 & 30.9 & 31.0 & 2.5 & 16.0 \\
Portugal & 1.1 & 1.2 & 1.1 & -3.1 & 1.3 \\
Spain & 4.5 & 1.2 & 10.3 & -1.7 & 6.8 \\
Denmark & 7.7 & 8.0 & 21.9 & & 9.8 \\
Sweden & 6.3 & 7.7 & 20.3 & -12.9 & 10.3 \\
United Kingdom & 10.8 & 16.0 & 9.7 & -21.6 & 22.9 \\
Norway & 16.1 & 11.7 & 29.9 & & 2.3 \\
Switzerland & 2.0 & 13.1 & 32.2 & 9.4 & 11.0 \\
\hline
\end{tabular}

Note: Methodology to calculate dollar exposures is described in section IV. Net dollar positions of banks (excluding securities, where possible) are calculated from data reported by national central banks (Austria, Finland, France, Germany, Ireland, Italy, Luxembourg, Netherlands, Portugal, Sweden, United Kingdom, Switzerland)(awaiting responses from the other central banks). 
Table 8. Impact of ‘Disruptive’ Dollar Shock

\begin{tabular}{lrrrr}
\hline Ratio to GDP & $\begin{array}{r}\text { FDI } \\
\text { Assets }\end{array}$ & $\begin{array}{r}\text { Portfolio } \\
\text { Equity }\end{array}$ & $\begin{array}{r}\text { Portfolio } \\
\text { Debt }\end{array}$ & Bank \\
Austria & -0.3 & -1.1 & -0.6 & 0.6 \\
Belgium & -1.0 & -0.8 & -3.4 & 0.4 \\
Finland & -0.8 & -0.7 & -0.9 & 0.6 \\
France & -1.8 & -1.1 & -0.03 & 0.9 \\
Germany & -1.5 & -0.5 & -0.9 & -0.9 \\
Greece & -0.1 & -0.2 & -0.1 & \\
Ireland & -2.1 & & & 1.9 \\
Italy & -0.3 & -0.8 & -0.05 & 0.5 \\
Luxembourg & -0.2 & & & -19.4 \\
Netherlands & -4.5 & -6.2 & -6.2 & -0.5 \\
Portugal & -0.2 & -0.2 & -0.2 & 0.6 \\
Spain & -0.9 & -0.2 & -2.1 & 0.3 \\
Denmark & -1.5 & -1.6 & -4.4 & \\
Sweden & -1.3 & -1.5 & -4.1 & 2.6 \\
United Kingdom & -2.2 & -3.2 & -1.9 & 4.3 \\
Norway & -3.2 & -2.3 & -6.0 & \\
Switzerland & -0.4 & -2.6 & -6.4 & -1.9 \\
\hline
\end{tabular}

Note: Impact effect (percent of GDP) of an unanticipated 20 percent dollar depreciation against the euro, consistent with 'disruptive' scenario in section III. 
Table 9. Current Account and Net Foreign Assets, 2005 (percent of GDP)

\begin{tabular}{lrrrr}
\hline & $\begin{array}{r}\text { Current } \\
\text { Account }\end{array}$ & $\begin{array}{r}\text { Net Foreign } \\
\text { Assets }\end{array}$ & Net equity & Net debt \\
& & & & \\
Austria & 1.3 & -18.4 & 2.6 & -21.0 \\
Belgium & 1.8 & 28.1 & 8.7 & 19.4 \\
Finland & 2.6 & -14.9 & -16.3 & 1.4 \\
France & -1.8 & 7.0 & 17.4 & -10.4 \\
Germany & 4.1 & 14.3 & 15.1 & -0.9 \\
Greece & -8.0 & -79.2 & -20.5 & -58.7 \\
Ireland & -0.8 & -19.4 & -236.1 & 211.4 \\
Italy & -1.5 & -13.7 & 16.4 & -30.1 \\
Luxembourg & 11.2 & 118.4 & -2740.8 & 2869.5 \\
Netherlands & 6.4 & -11.8 & 20.6 & -32.4 \\
Portugal & -9.3 & -64.6 & -29.5 & -35.1 \\
Spain & -7.4 & -44.5 & -6.7 & -37.8 \\
Denmark & 3.2 & 1.1 & 21.8 & -20.7 \\
Norway & 16.7 & 75.0 & 50.1 & 24.9 \\
Sweden & 6.6 & -8.6 & 37.4 & -46.0 \\
Switzerland & 13.8 & 93.1 & 6.7 & 86.3 \\
United Kingdom & -2.6 & -16.8 & 16.8 & -33.7 \\
Central and Eastern Europe & -4.6 & -46.0 & -38.5 & -7.5 \\
\hline
\end{tabular}

Note: Data for 2005 where available, 2004 otherwise (indicated by an asterisk). Central and Eastern Europe comprises Bulgaria, Croatia, Czech Republic, Estonia, Latvia, Lithuania, Hungary, Poland, Romania, Slovak Republic, and Slovenia. Sources: authors' calculations based on Lane and Milesi-Ferretti (2006a and World Economic Outlook database. 
Appendix Table 1. Assumptions on the Composition of Capital Flows (2006-2015)

\begin{tabular}{|c|c|c|}
\hline & United States & \\
\hline Type of flow & Assumptions & Avg value \\
\hline Direct investment abroad & Constant ratio of GDP & $1.4 \%$ \\
\hline Portfolio equity investment abroad & Constant ratio of GDP & $1.0 \%$ \\
\hline Portfolio debt investment abroad & Constant ratio of GDP & $0.4 \%$ \\
\hline Other investment abroad & Constant ratio of GDP & $2.5 \%$ \\
\hline Reserves & none & 0 \\
\hline Direct investment in the country & Constant ratio of GDP & $1.4 \%$ \\
\hline Portfolio equity invest. in the country & Constant ratio of GDP & $1.0 \%$ \\
\hline Portfolio debt invest. in the country & Residual to ensure that net capital flows=CA balance & $5.4 \%$ \\
\hline \multirow[t]{2}{*}{ Other investment in the country } & Constant ratio of GDP & $2.5 \%$ \\
\hline & Euro Area & \\
\hline Type of flow & Assumptions & Avg value \\
\hline Direct investment abroad & Constant ratio of GDP & $2.5 \%$ \\
\hline Portfolio equity investment abroad & Constant ratio of GDP & $1.5 \%$ \\
\hline Portfolio debt investment abroad & Residual to ensure that net capital flows=CA balance & $3.2 \%$ \\
\hline Other investment abroad & Constant ratio of GDP & $3.5 \%$ \\
\hline Reserves & none & $0.0 \%$ \\
\hline Direct investment in the country & Constant ratio of GDP & $2.5 \%$ \\
\hline Portfolio equity invest. in the country & Constant ratio of GDP & $1.5 \%$ \\
\hline Portfolio debt invest. in the country & Constant ratio of GDP & $3.0 \%$ \\
\hline \multirow[t]{2}{*}{ Other investment in the country } & Constant ratio of GDP & $3.5 \%$ \\
\hline & Japan & \\
\hline Type of flow & Assumptions & Avg value \\
\hline Direct investment abroad & Constant ratio of GDP & $1.0 \%$ \\
\hline Portfolio equity investment abroad & Constant ratio of GDP & $1.0 \%$ \\
\hline Portfolio debt investment abroad & Residual to ensure that net capital flows=CA balance & $2.8 \%$ \\
\hline Other investment abroad & Constant ratio of GDP & $1.0 \%$ \\
\hline Reserves & Constant ratio of GDP & $0.5 \%$ \\
\hline Direct investment in the country & Constant ratio of GDP & $0.2 \%$ \\
\hline Portfolio equity invest. in the country & Constant ratio of GDP & $1.0 \%$ \\
\hline Portfolio debt invest. in the country & Constant ratio of GDP & $1.0 \%$ \\
\hline \multirow[t]{2}{*}{ Other investment in the country } & Constant ratio of GDP & $1.0 \%$ \\
\hline & China & \\
\hline Type of flow & Assumptions & Avg value \\
\hline Direct investment abroad & Gradually increasing ratio of GDP & $0.6 \%$ \\
\hline Portfolio equity investment abroad & Gradually increasing ratio of GDP & $0.5 \%$ \\
\hline Portfolio debt investment abroad & Gradually increasing ratio of GDP & $0.4 \%$ \\
\hline Other investment abroad & Constant ratio of GDP & $0.8 \%$ \\
\hline Reserves & Residual to ensure that net capital flows=CA balance & $8.0 \%$ \\
\hline Direct investment in the country & Gradually declining ratio of GDP & $3.0 \%$ \\
\hline Portfolio equity invest. in the country & Constant ratio of GDP from 2007 & $0.9 \%$ \\
\hline Portfolio debt invest. in the country & Gradually increasing ratio of GDP & $0.4 \%$ \\
\hline Other investment in the country & Constant ratio of GDP & $0.9 \%$ \\
\hline
\end{tabular}

Note: the average value for the residual category of capital flows changes across scenarios (because the current account balances change). The reported value corresponds to the baseline scenario. 
Figure 1. Current Account Balances, Major Regions, 1997-2005

$$
\text { (percent of world GDP) }
$$

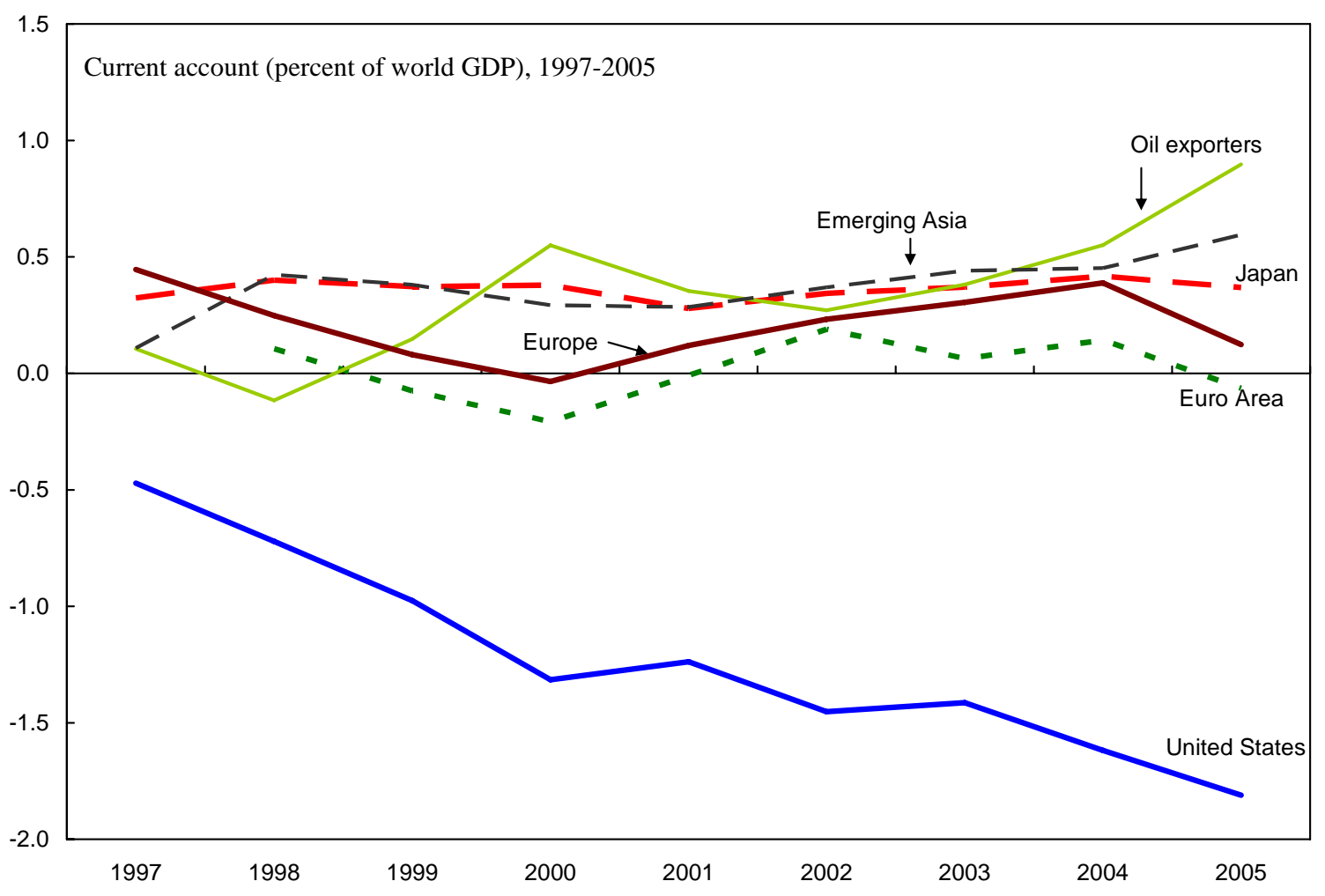

Note: Emerging Asia group includes: Hong Kong S.A.R., India, Indonesia, Korea, Malaysia, Philippines, Singapore, Taiwan province of China, and Thailand. The Europe group includes the 12 euro area countries plus Denmark, Iceland, Norway, Sweden, Switzerland, and the United Kingdom. The oil exporters' group includes: Algeria, Angola, Azerbaijan, Bahrain, Republic of Congo, Ecuador, Equatorial Guinea, Gabon, Iran, Kuwait, Libya, Nigeria, Oman, Qatar, Russia, Saudi Arabia, Syrian Arab Republic, Turkmenistan, United Arab Emirates, Venezuela, and Yemen. Source: IMF, Balance of Payments Statistics. 
Figure 2. Current Account Balances: Europe versus the United States (percent of GDP)

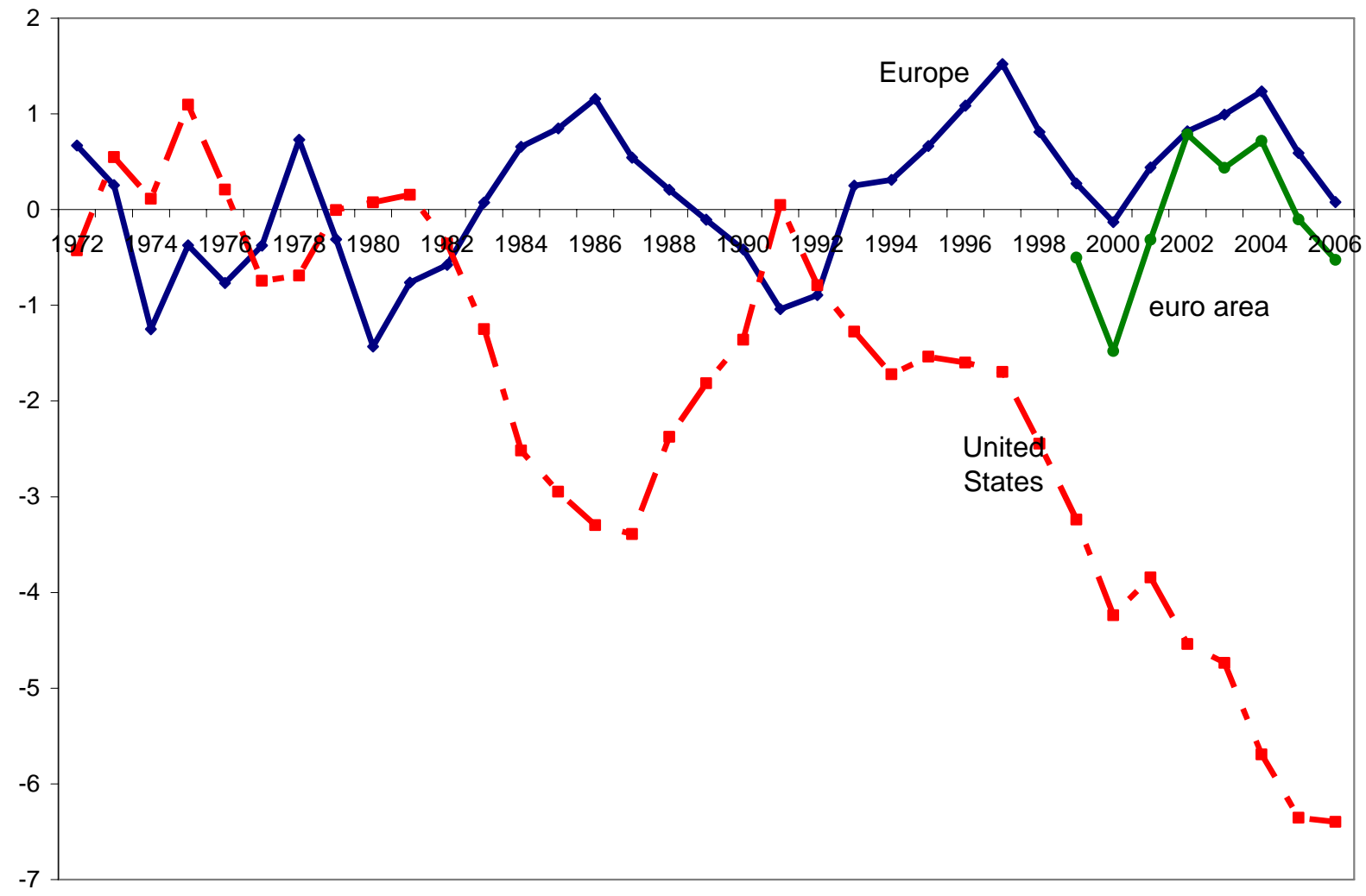

Note: the chart depicts current account balances in percent of each region's GDP. Aggregate Europe includes the 12 euro area countries plus Denmark, Iceland, Norway, Sweden, Switzerland, and the United Kingdom. Source: IMF, Balance of Payments Statistics. 
Figure 3. Current Account: Aggregate Balance of Europe, Japan, and United States (percent of GDP)

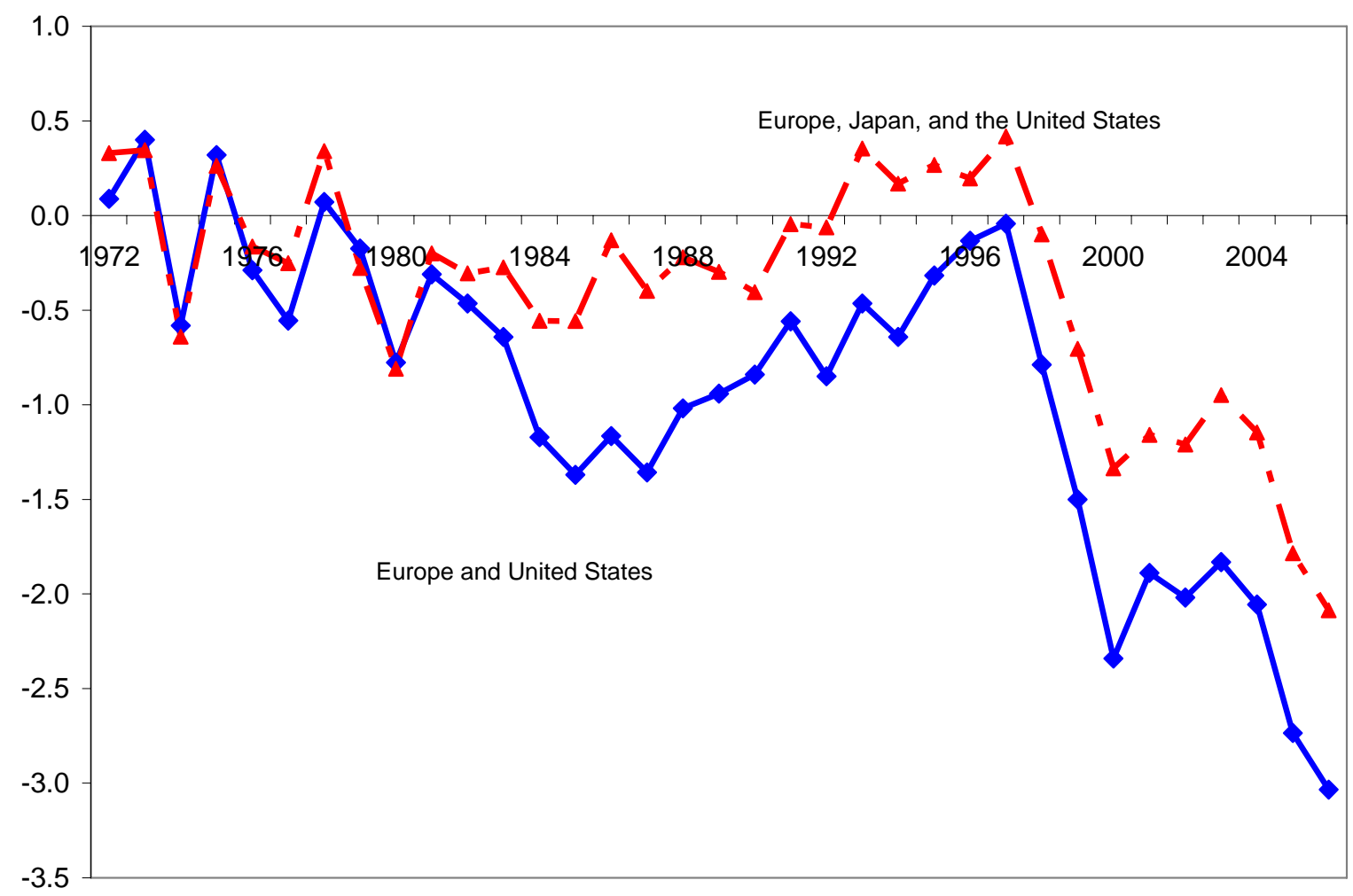

Note: the chart depicts the aggregate current account balance of the two country groups, scaled by their combined GDP. Source: IMF, Balance of Payments Statistics. 
Figure 4. Net Foreign Asset Positions: Europe and the United States (percent of GDP)

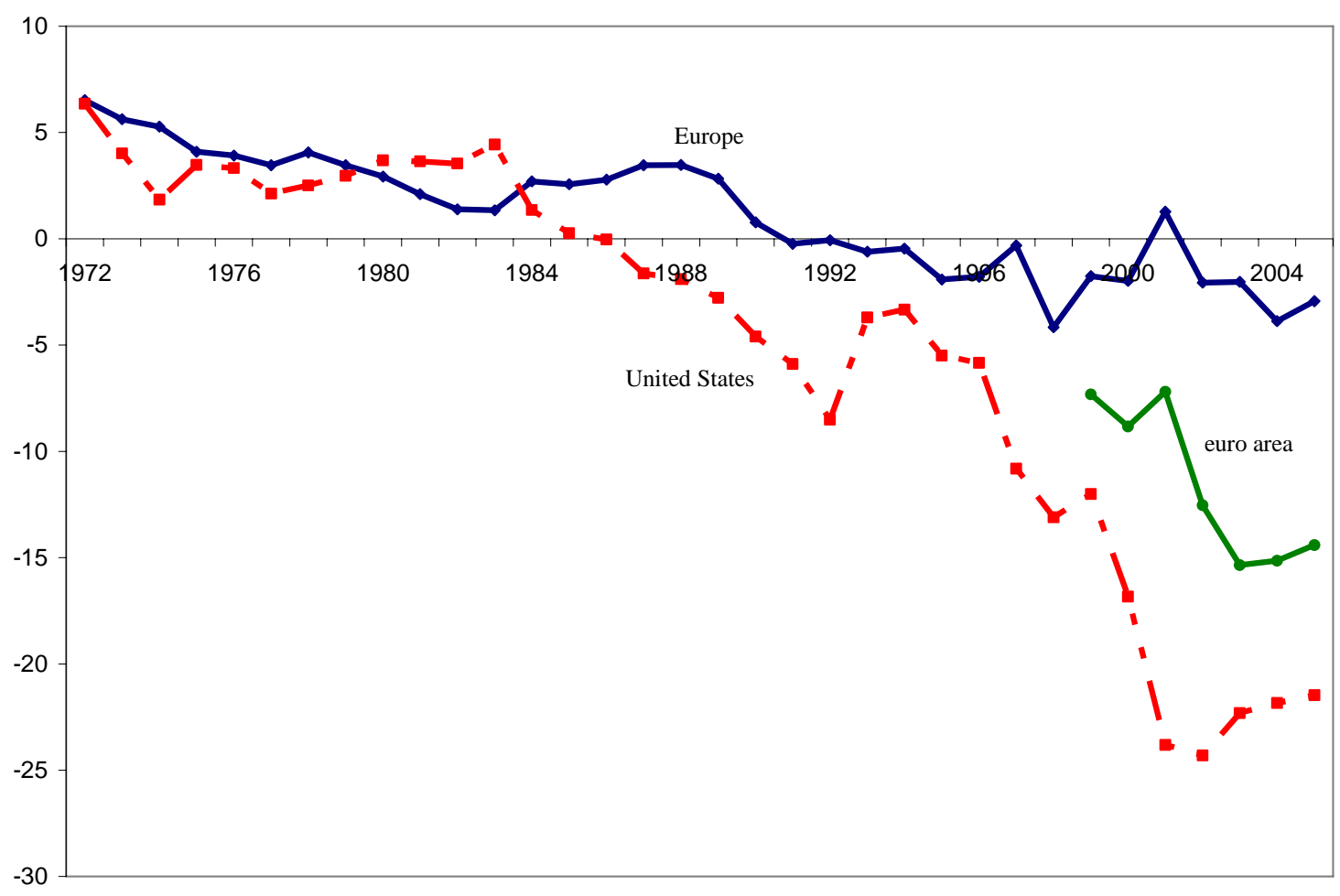

Source: authors' calculations based on Lane and Milesi-Ferretti (2006) and national data. 
Figure 5. The International Financial Integration of Europe (percent of GDP)

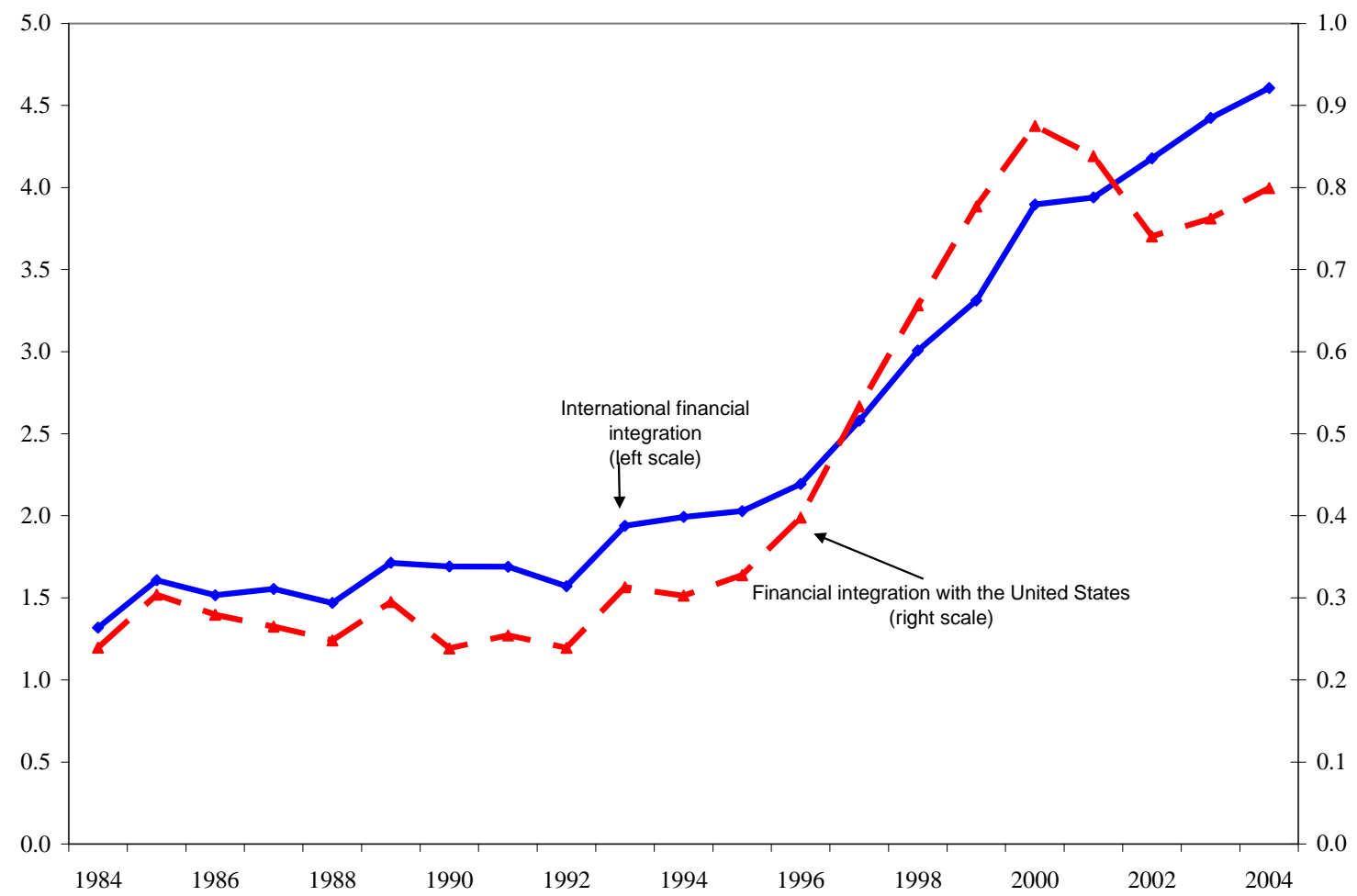

Note: International financial integration is defined as the sum of foreign assets and liabilities (as a ratio to GDP) for a group of European countries, including intra-European cross-holdings. Financial integration with the United States is the sum of U.S.-located foreign assets and liabilities (as a ratio to GDP) for this group of countries. Source: Lane and Milesi-Ferretti (2006a) and other sources described in Section II. 
Figure 6. Adjustment of Global Imbalances
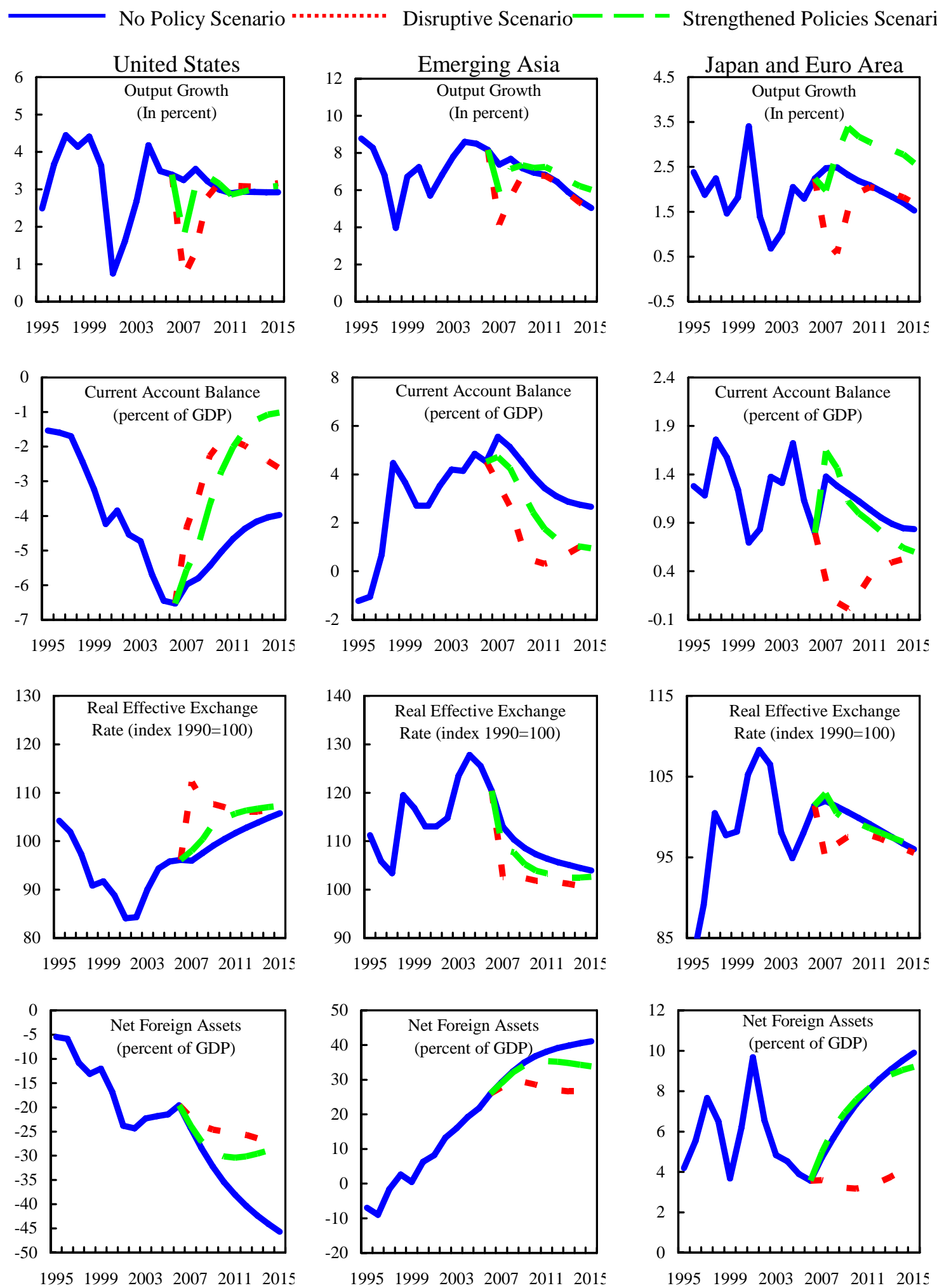

Source: IMF, World Economic Outlook, September 2006 and authors' calculations. 
Figure 7. Europe's Current Account Balances (percent of GDP)
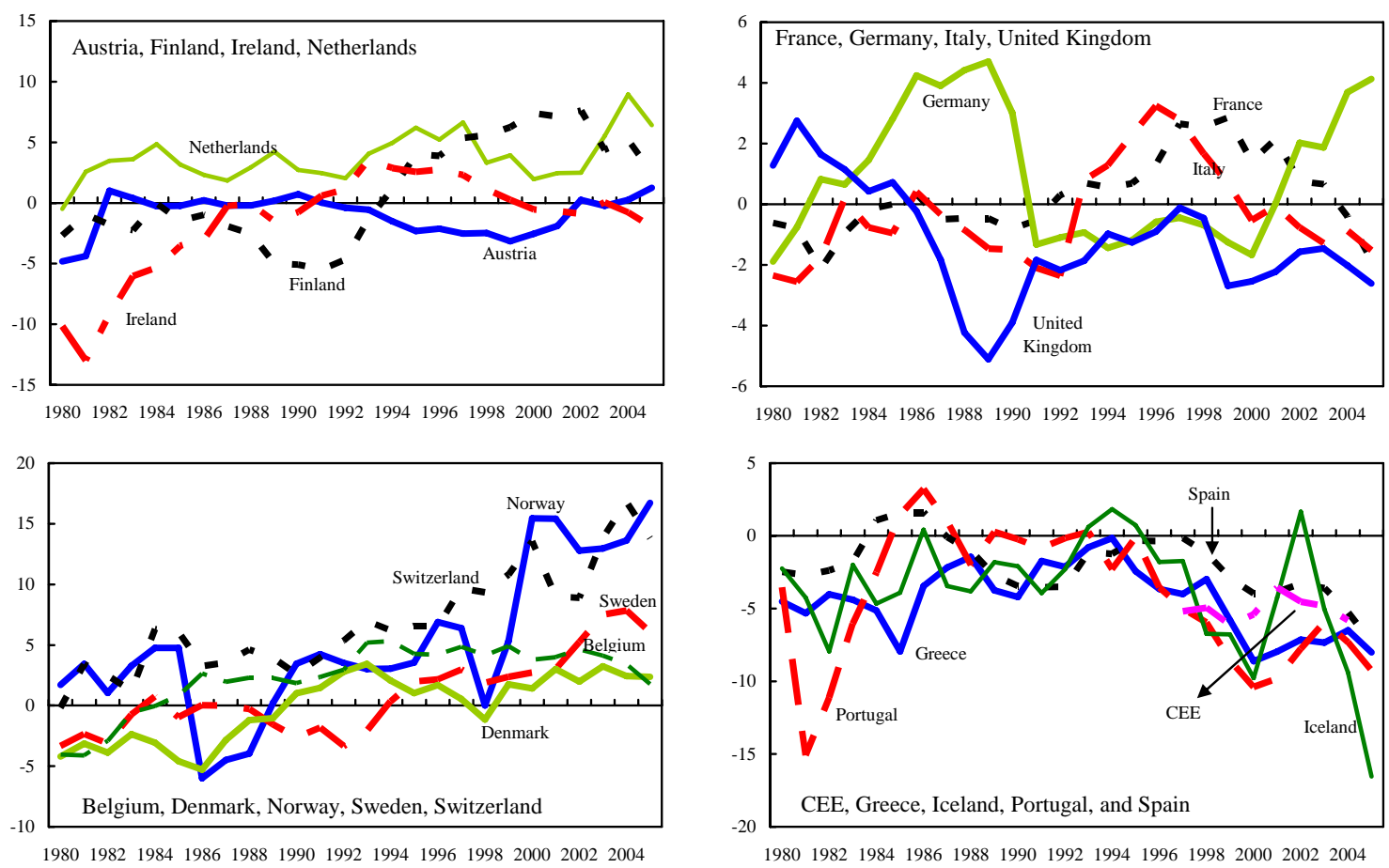

Source: IMF, Balance of Payments Statistics. 
Figure 8. Europe’s Net Foreign Assets

(percent of GDP)
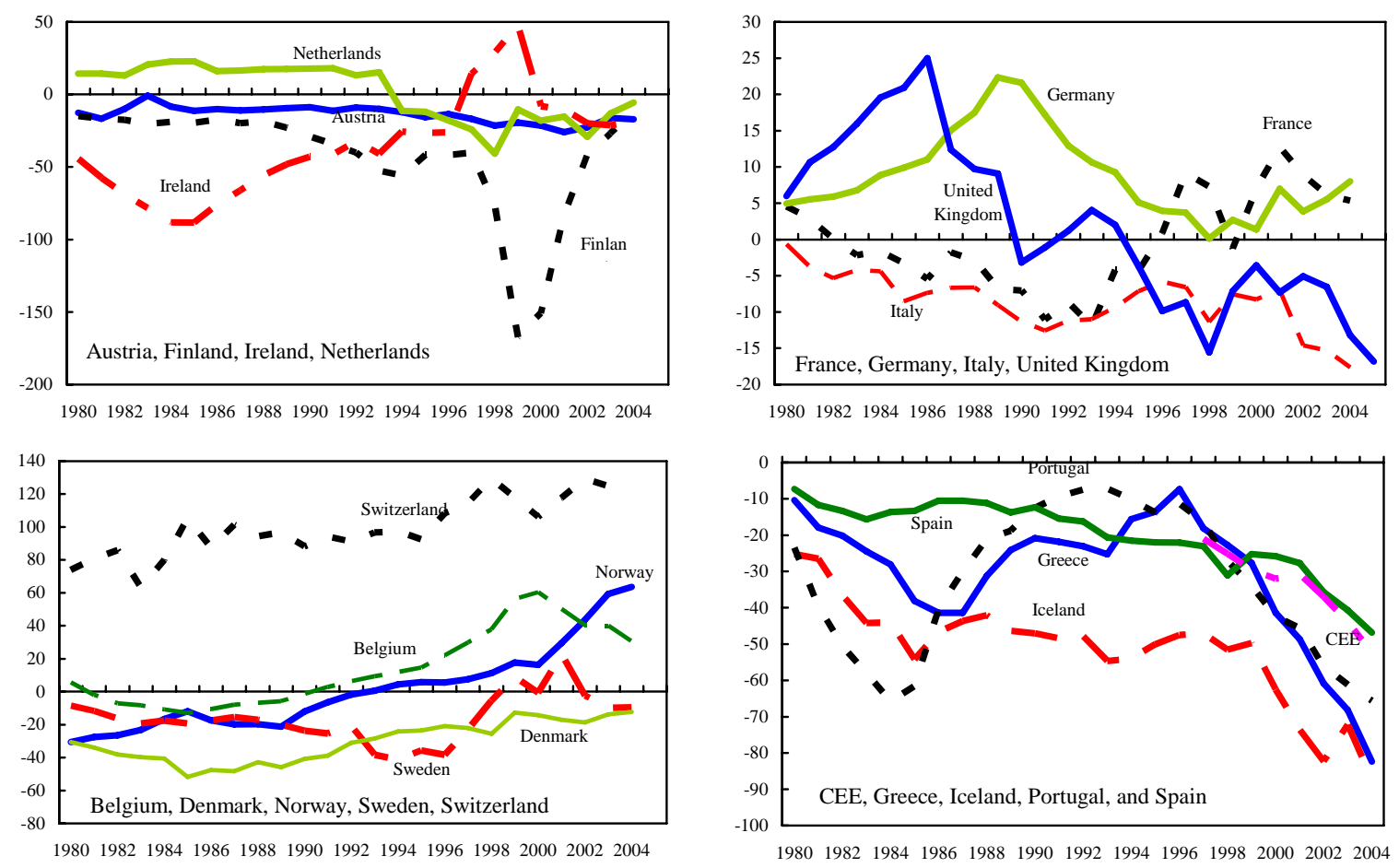

Source: Lane and Milesi-Ferretti (2006). 